Article

\title{
Carrier Compensation Induced by Thermal Annealing in Al-Doped ZnO Films
}

\author{
Takashi Koida ${ }^{1, *}$, Tetsuya Kaneko ${ }^{1,2}$ and Hajime Shibata ${ }^{1}$ \\ 1 Research Center for Photovoltaics, National Institute of Advanced Industrial Science and Technology (AIST), \\ Central 2, Umezono 1-1-1, Tsukuba, Ibaraki 305-8568, Japan; tetsuya-kaneko@tokai-u.jp (T.K.); \\ h.shibata@aist.go.jp (H.S.) \\ 2 School of Engineering, Tokai University, 4-1-1, Kitakaname, Hiratsuka, Kanagawa 259-1292, Japan \\ * Correspondence: t-koida@aist.go.jp; Tel.: +81-29-861-3448
}

Academic Editors: Andrea Li Bassi and Carlo S. Casari

Received: 26 December 2016; Accepted: 3 February 2017; Published: 8 February 2017

\begin{abstract}
This study investigated carrier compensation induced by thermal annealing in sputtered $\mathrm{ZnO}: \mathrm{Al}\left(\mathrm{Al}_{2} \mathrm{O}_{3}: 0.25,0.5,1.0\right.$, and $\left.2.0 \mathrm{wt} \%\right)$ films. The films were post-annealed in a $\mathrm{N}_{2}$ atmosphere at low $\left(1 \times 10^{-23} \mathrm{~atm}\right)$ and high $\left(1 \times 10^{-4} \mathrm{~atm}\right)$ oxygen partial pressures $\left(P_{\mathrm{O} 2}\right)$. In $\mathrm{ZnO}$ :Al films with low $\mathrm{Al}$ contents (i.e., $0.25 \mathrm{wt} \%$ ), the carrier density $(n)$ began to decrease at annealing temperatures $\left(T_{\mathrm{a}}\right)$ of $600{ }^{\circ} \mathrm{C}$ at low $P_{\mathrm{O} 2}$. At higher $P_{\mathrm{O} 2}$ and / or Al contents, $n$ values began to decrease significantly at lower $T_{\mathrm{a}}\left(\mathrm{ca} .400^{\circ} \mathrm{C}\right)$. In addition, $\mathrm{Zn}$ became desorbed from the films during heating in a high vacuum (i.e., $<1 \times 10^{-7} \mathrm{~Pa}$ ). These results suggest the following: (i) $\mathrm{Zn}$ interstitials and $\mathrm{Zn}$ vacancies are created in the $\mathrm{ZnO}$ lattice during post-annealing treatments, thereby leading to carrier compensation by acceptor-type $\mathrm{Zn}$ vacancies; (ii) The compensation behavior is significantly enhanced for $\mathrm{ZnO}: \mathrm{Al}$ films with high $\mathrm{Al}$ contents.
\end{abstract}

Keywords: transparent conducting oxides; $\mathrm{ZnO}$; doping; carrier compensation; mobility

\section{Introduction}

Transparent conducting oxide (TCO) films have been widely used as window electrodes in optoelectronic devices such as flat panel displays and solar cells. Most TCO films are based on $\mathrm{In}_{2} \mathrm{O}_{3}, \mathrm{SnO}_{2}$, or $\mathrm{ZnO}$, of which $\mathrm{ZnO}$ is the most important due to its advantages of low cost and nontoxicity compared to $\mathrm{In}_{2} \mathrm{O}_{3}$. Additionally, $\mathrm{ZnO}$ films exhibit higher conductivity than $\mathrm{SnO}_{2}$ films at relatively low growth temperatures. Recently, $\mathrm{ZnO}$ films have been used in thin-film solar cell applications [1], however, they typically exhibit low conductivity compared to $\operatorname{In}_{2} \mathrm{O}_{3}$-based TCO [2]. The most important properties of TCO films for use as window electrodes are their conductivity and absorption coefficient. Both of these parameters are related to the carrier density $(n)$ and mobility $(\mu)$ [3]. The carrier density $\left(n=N_{\mathrm{d}}-N_{\mathrm{a}}\right)$ is determined by the donor $\left(N_{\mathrm{d}}\right)$ and acceptor $\left(N_{\mathrm{a}}\right)$ densities, and these two values influence $\mu$ through Coulomb interactions that cause free electron scattering by charged donor and acceptor defects. In the case of $\mathrm{Al}$-doped $\mathrm{ZnO}$ ( $\mathrm{ZnO}: \mathrm{Al})$ films, for example, the dominant donor is the singly charged dopant $\mathrm{Al}_{\mathrm{Zn}} \bullet$, whereas the compensating acceptor is considered to be a doubly charged zinc vacancy $\left(\mathrm{v}_{Z n}{ }^{\prime \prime}\right)$ [4-7]. Hence, suppressing $\mathrm{v}_{\mathrm{Zn}}$ " is important for achieving both high $n$ and $\mu$. 
The changes in concentration of intrinsic defects such as $\mathrm{v}_{Z \mathrm{n}}$ " are typically described using Brouwer diagrams [8]. Lany et al. calculated intrinsic defect densities and $n$ for pure $\mathrm{ZnO}$ and $\mathrm{ZnO}: \mathrm{Al}$ as a function of growth temperature and oxygen partial pressure $\left(\mathrm{P}_{\mathrm{O} 2}\right)$ based on the formation energies of the defects and the thermodynamics of the relevant defect reactions [6]. In $\mathrm{Zn}_{0.99} \mathrm{Al}_{0.01} \mathrm{O}$, the donor density remains uncompensated at low $P_{\mathrm{O} 2}$, whereas $n$ decreases with increasing $P_{\mathrm{O} 2}$ as a result of compensation by the $\mathrm{v}_{\mathrm{Zn}}$ " acceptor. Zakutayev et al. have also investigated the connection between defect theory and thin-film growth of $\mathrm{ZnO}: \mathrm{Ga}$ by comparing theoretically and experimentally obtained $n$ values [9]. They demonstrated that the high conductivity of the films was due to the highly non-equilibrium, metastable state that resulted from growth by pulsed laser deposition (PLD) at relatively low temperatures and low $P_{\mathrm{O} 2}$. In addition, Look et al. determined $N_{\mathrm{d}}$ and $N_{\mathrm{a}}$ densities from $\mu$ and $n$ values for ZnO:Ga thin films grown by PLD based on a mobility analysis in which $\mu$ was mainly determined by the scattering from ionized donors and acceptors [10].

The purpose of the present work is to investigate the carrier compensation behavior in sputtered $\mathrm{ZnO}: \mathrm{Al}$ films during post-annealing treatment at low $\left(1 \times 10^{-23} \mathrm{~atm}\right)$ and high $P_{\mathrm{O} 2}\left(1 \times 10^{-4} \mathrm{~atm}\right)$. Because the sputtering process is known to be a non-equilibrium method, the as-deposited $\mathrm{ZnO}: \mathrm{Al}$ films are far from an equilibrium state. During post-annealing at high temperatures under constant $P_{\mathrm{O} 2}$, the film equilibrates with $\mathrm{O}_{2}$ through interaction with the surrounding gas phase. Consequently, the density of $\mathrm{v}_{\mathrm{Zn}}$ " defects should approach a certain value determined by the $P_{\mathrm{O} 2}$ and annealing temperature. Therefore, monitoring the variation of $n$ values can be used to evaluate carrier compensation induced by the thermal annealing.

We characterized $\mathrm{ZnO}: \mathrm{Al}$ films with various $\mathrm{Al}$ contents. Theoretically, the density of compensating acceptor-type $\mathrm{v}_{Z \mathrm{n}}$ " increases with the concentration of donor-type $\mathrm{Al}_{\mathrm{Zn}} \bullet$ because the formation energy of $\mathrm{v}_{Z \mathrm{n}}$ " decreases with increases in the Fermi energy [4-7]. At the same time, the Al content of the films typically influences the optimum film growth temperature [11,12], and the extent of non-equilibrium in the as-deposited films increases with decreasing growth temperatures $\left(T_{\mathrm{g}}\right)$. In this paper, we first describe the effects of $T_{\mathrm{g}}$ on the structural and electrical properties of $\mathrm{ZnO}: \mathrm{Al}$ films with different $\mathrm{Al}$ contents. After optimizing $T_{\mathrm{g}}$ for each $\mathrm{ZnO}: \mathrm{Al}$ film, we describe the variations in $n$ and $\mu$ values during the post-annealing treatment at low and high $P_{\mathrm{O} 2}$ and discuss the origin of the variations.

\section{Results and Discussion}

\subsection{Properties of As-Deposited $\mathrm{ZnO}$ :Al Films}

Figure 1 shows (a) $\theta-2 \theta$ scan (out-of-plane) with $002 \omega$ scan and (b) $2 \theta_{x}-\varphi$ scan (in-plane) X-ray diffraction (XRD) patterns of a 240-nm-thick $\mathrm{ZnO}: \mathrm{Al}(2.0 \mathrm{wt} \%)$ film grown at $250{ }^{\circ} \mathrm{C}$ as an example. Only the diffraction peaks due to (002) and (004) planes were observed in the $\theta-2 \theta$ scan, whereas the diffraction peaks due to (100), (110), (200), (210), and (300) planes were observed. All of the prepared films with various $\mathrm{Al}$ contents and $T_{\mathrm{g}}$ exhibited preferred orientation of the $c$-axis normal to the substrate plane and did not contain any additional phases (e.g., $\mathrm{ZnAl}_{2} \mathrm{O}_{4}$ or $\mathrm{Al}_{2} \mathrm{O}_{3}$ phases). Because the solid solubility limit of $\mathrm{Al}$ in $\mathrm{Al}_{2} \mathrm{O}_{3}$-doped $\mathrm{ZnO}$ sintered body prepared at $1400{ }^{\circ} \mathrm{C}$ was reported to be $\sim 0.3$ at \% [13], the $\mathrm{ZnO}$ : Al films fabricated in this study are metastable from a thermodynamic point of view, and a supersaturated solid solution occurs as a result of the highly non-equilibrium growth process. Figure 2 shows a cross-sectional transmission electron microscopy (TEM) image of the $\mathrm{ZnO}: \mathrm{Al}(2.0 \mathrm{wt} \%)$ film. Abundant small columnar grains were present at the interface between the film and substrate, which had slightly tilted long-axis orientations normal to the substrate surface. For film thicknesses above $50 \mathrm{~nm}$, the small grains became connected, and the deviation of each columnar grain decreased. Consequently, relatively large columnar grains with widths of 20-40 nm appeared when the film thickness exceeded $100 \mathrm{~nm}$. 


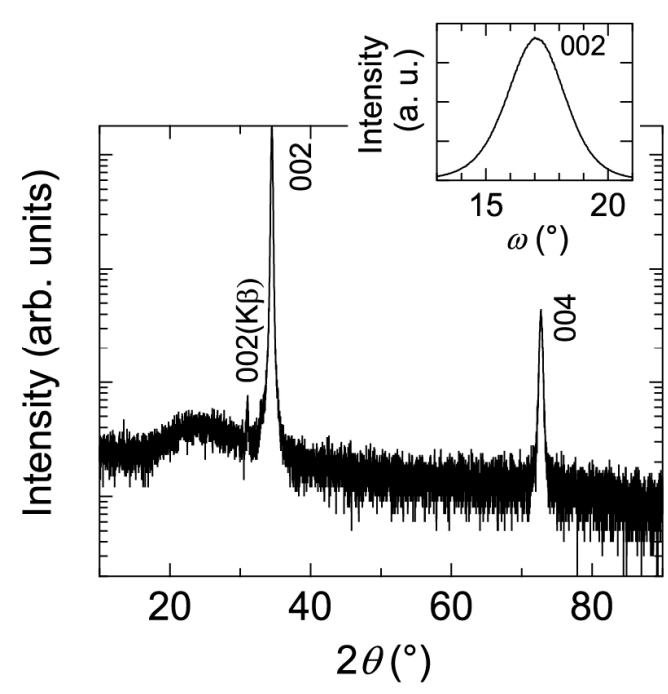

(a)

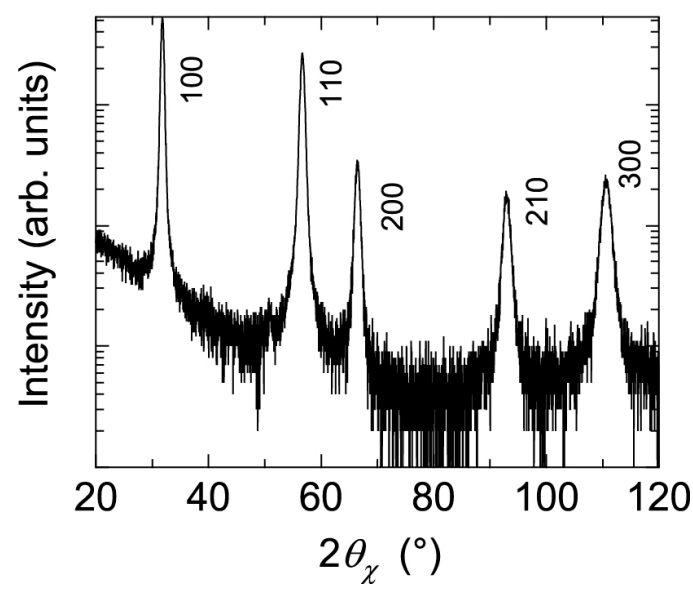

(b)

Figure 1. (a) $\theta-2 \theta$ scan (out-of-plane) with $002 \omega$ scan; and (b) $2 \theta_{x}-\varphi$ scan (in-plane) XRD patterns of a $\mathrm{ZnO}: \mathrm{Al}(2.0 \mathrm{wt} \%)$ film.

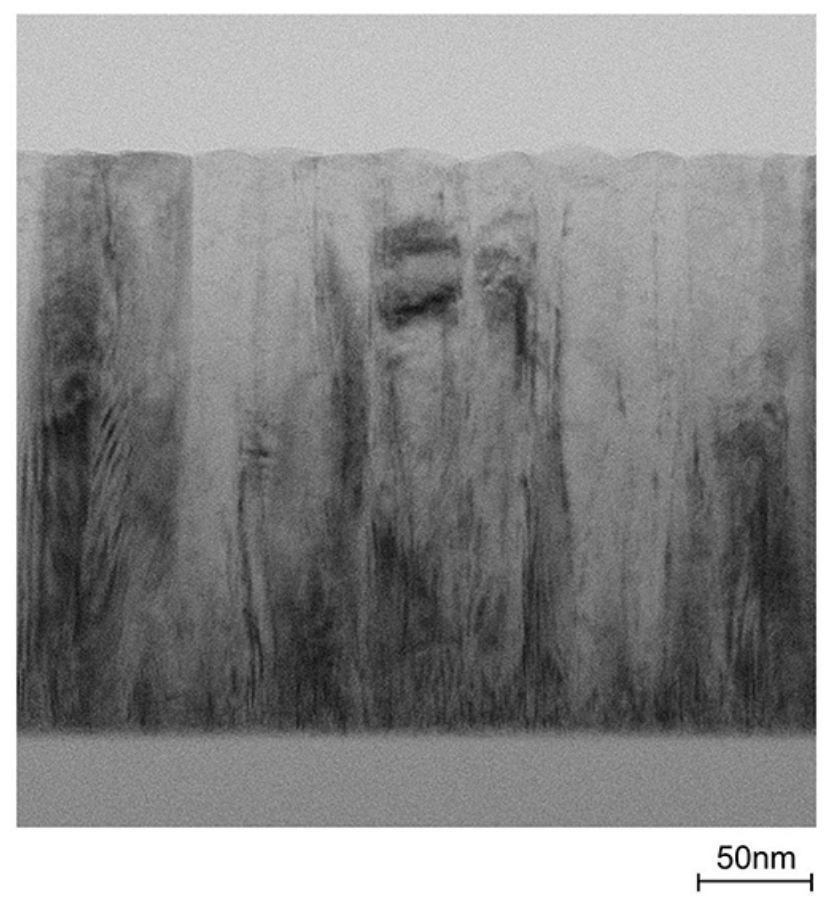

Figure 2. A cross-sectional TEM image of an as-deposited $\mathrm{ZnO}: \mathrm{Al}(2.0 \mathrm{wt} \%)$ film.

Figure 3 displays plots of the $c$-axis length, the full width at half maximum (FWHM) of the 002 diffraction peak $\left(\mathrm{FWHM}_{002}\right)$, and the FWHM of rocking curves for the 002 diffraction peak $\left(\mathrm{FWHM} \omega_{002}\right)$ as a function of $T_{\mathrm{g}}$ for the $\sim 240$-nm-thick $\mathrm{ZnO}$ :Al films. Here, $\mathrm{FWHM}_{002}$ reflects the out-of-plane crystallite size and the differences in $c$-axis length along the growth direction due to non-uniform micro-stresses, whereas FWHM $\omega_{002}$ reflects the $c$-axis tilt. For each $\mathrm{ZnO}: \mathrm{Al}$ film with a given $\mathrm{Al}$ content, $\mathrm{FWHM}_{002}$ and $\mathrm{FWHM} \omega_{002}$ decreased gradually with increasing $T_{\mathrm{g}}$ up to a certain optimal temperature ( $T_{\text {opt }}$ ), while these values increased above $T_{\text {opt }}$. The values of $T_{\text {opt }}$ were $250,300,350$, and $370{ }^{\circ} \mathrm{C}$ for $\mathrm{ZnO}: \mathrm{Al}$ films fabricated using $\mathrm{ZnO}$ ceramic targets containing 2.0, 1.0, 0.5, and $0.25 \mathrm{wt} \% \mathrm{Al}_{2} \mathrm{O}_{3}$, respectively. $T_{\text {opt }}$ decreases with increasing $\mathrm{Al}$ content. The variation of the FWHM values can be 
explained as follows: The diffusion length of adatoms and precursors at the growth surface increase with $T_{\mathrm{g}}$ up to $T_{\mathrm{opt}}$, thereby leading to greater crystallinity in the films. Conversely, further increases in $T_{\mathrm{g}}$ would significantly promote diffusion of the adatoms and precursors, leading to migration of ions in the bulk films, and desorption of $\mathrm{Zn}$ at the growth surface. Consequently, excess Al may degrade the film crystallinity by forming local atomic structures similar to a homologous phase $\left((\mathrm{ZnO})_{\mathrm{m}} \mathrm{Al}_{2} \mathrm{O}_{3}\right)[14,15]$. The effect of inserting homologous phases in a $\mathrm{ZnO}$ film would be to increase the out-of-plane dimension of the film. Indeed, we observed an increase in the $c$-axis length at $T_{\mathrm{g}}$ above $T_{\text {opt }}$ (Figure 3).

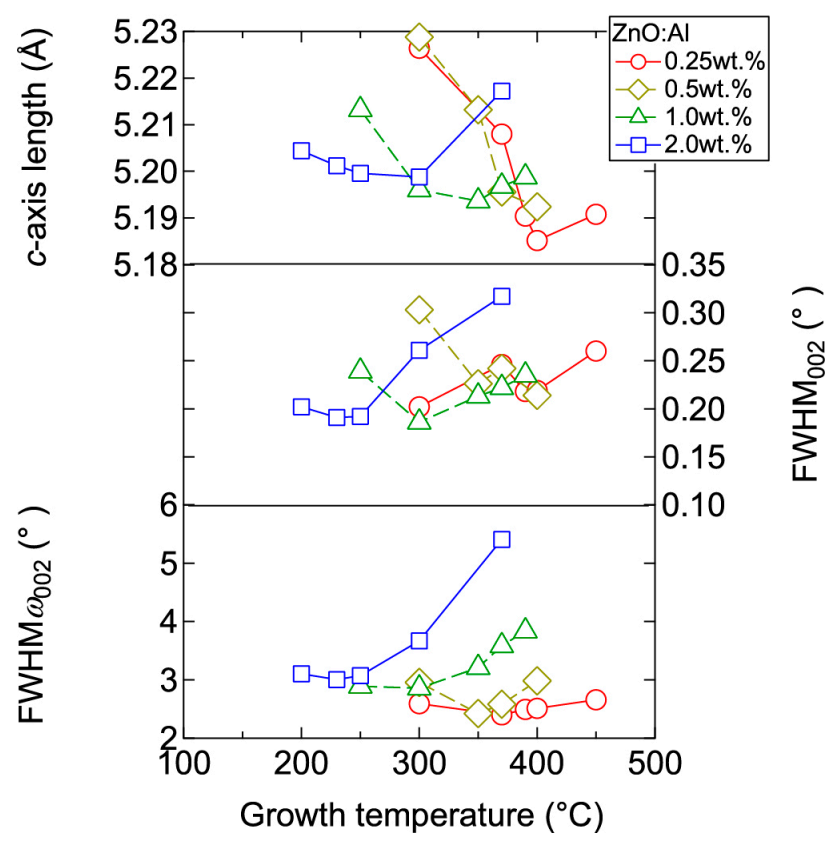

Figure 3. Plots of $c$-axis length, the full width at half maximum (FWHM) of the 002 diffraction peak $\left(\mathrm{FWHM}_{002}\right)$, and the FWHM of rocking curves for the 002 diffraction peak $\left(\mathrm{FWHM} \omega_{002}\right)$ as a function of growth temperature for $\mathrm{ZnO}: \mathrm{Al}(0.25,0.5,1.0$, and $2.0 \mathrm{wt} \%)$ films.

Figure 4 displays the resistivity $(\rho), n$, and $\mu$ of the films plotted as a function of $T_{\mathrm{g}}$. With decreasing Al content, $n$ monotonically decreased along with a gradual increase in $\mu$. Consequently, $\rho$ gradually increased with decreasing Al content. More importantly, in each ZnO:Al (0.25, 0.5, 1.0, and $2.0 \mathrm{wt} \%$ ) film, both $n$ and $\mu$ exhibited maximum values at the $T_{\text {opt }}$ values indicated in Figure 3 . The results suggest that imperfections of crystal are the cause of carrier trapping and scattering. This phenomenon is also observed in $\mathrm{ZnO}: \mathrm{Al}$ films prepared at different film thicknesses. Figure 5 shows $c$-axis length, $\mathrm{FWHM}_{002}$, and FWHM $\omega_{002}$ as a function of film thickness for each ZnO:Al film deposited at $T_{\text {opt }}$. Regardless of $\mathrm{Al}$ content, both $\mathrm{FWHM}_{002}$ and $\mathrm{FWHM} \omega_{002}$ decreased rapidly with increasing film thickness up to 100-200 nm, and decreased gradually over 100-200 nm. Corresponding to the change in crystalline quality, both $n$ and $\mu$ increased rapidly with increasing film thickness up to 100-200 nm, and increased gradually over 100-200 nm for each $\mathrm{ZnO}: \mathrm{Al}(0.25,0.5,1.0$, and $2.0 \mathrm{wt} \%)$, as shown in Figure $6 \mathrm{a}$. Figure $6 \mathrm{~b}$ plots a relationship between $n$ and $\mu$. In Figure $6 \mathrm{~b}$, thick solid lines are connected to the films having similar film thicknesses. In general, mobility of degenerated semiconductors decreases with increase in carrier density, since donor impurities work as scattering centers of free carriers. Indeed, measured $\mu$ for thick films with a thickness of $\sim 800 \mathrm{~nm}$ decreased with an increase in $\mathrm{Al}$ content or $n$. However, for thin films with a thickness of less than $100 \mathrm{~nm}$, mobility increased with carrier density. The behavior can be explained on the basis of scattering at the grain boundary (GB) rather than ionized impurities [16,17]. GB scattering is described by the Seto model, in which the mobility is dominated by thermionic emission across grain barriers, where impurities or other defects 
induce electron traps at GBs [16]. For films with very high $n$ values, the depletion width formed at a GB is narrow, enabling tunneling through the barriers by free electrons. These results shown in Figures 3-6 clearly indicate that imperfections in the crystal lattice and concentration of GB are the cause of carrier trapping and scattering. It should be noted that the values of $n, \mu$, and $T_{\text {opt }}$ obtained for each $\mathrm{ZnO}: \mathrm{Al}$ are comparable to those previously reported for $\mathrm{ZnO}: \mathrm{Al}$ films $[11,12,18]$.

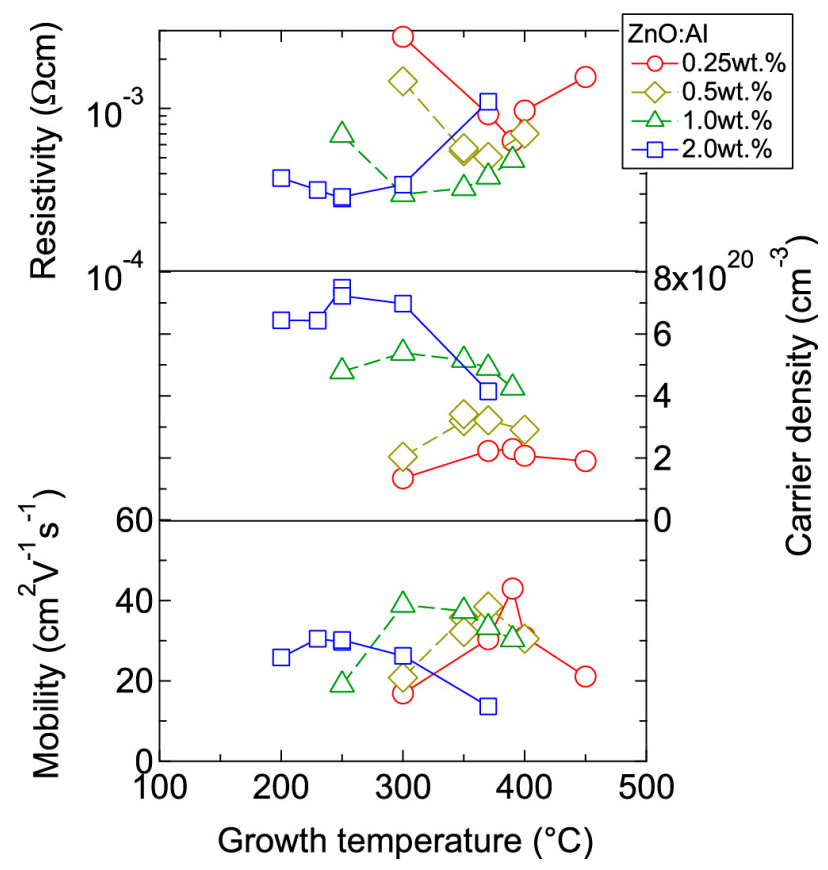

Figure 4. Plots of resistivity, carrier density, and mobility in $\mathrm{ZnO}: \mathrm{Al}(0.25,0.5,1.0$, and 2.0 wt \%) films as a function of growth temperature.

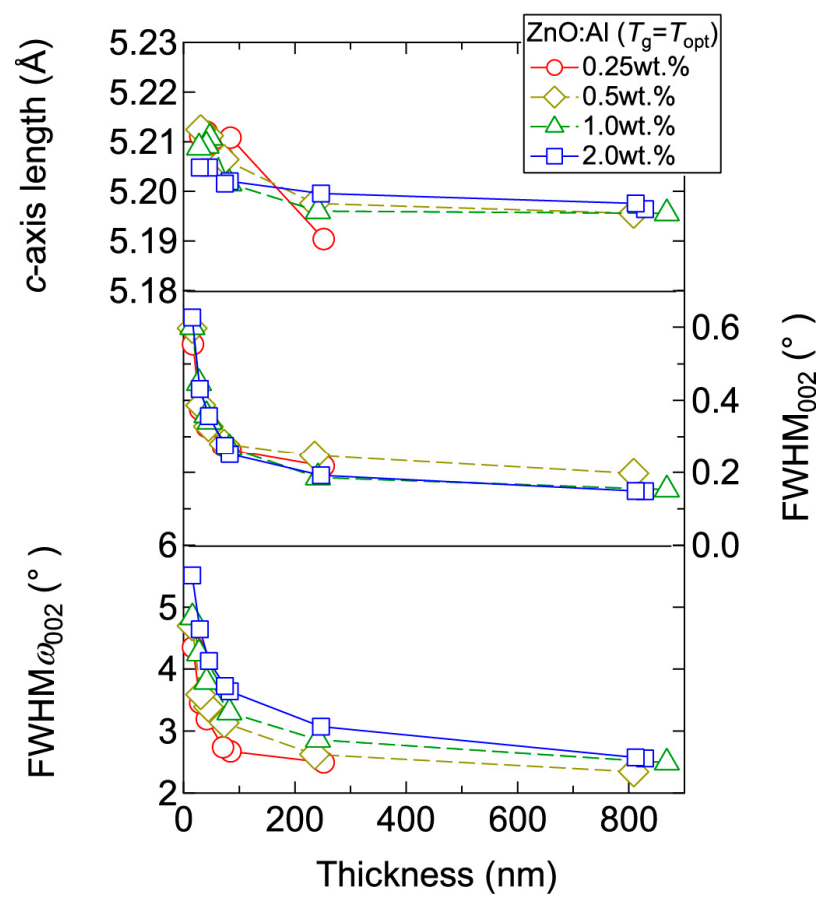

Figure 5. Plots of $c$-axis length, the FWHM of the 002 diffraction peak $\left(\mathrm{FWHM}_{002}\right)$, and the FWHM of rocking curves for the 002 diffraction peak $\left(\mathrm{FWHM} \omega_{002}\right)$ as a function of thickness for $\mathrm{ZnO}: \mathrm{Al}(0.25$, $0.5,1.0$, and $2.0 \mathrm{wt} \%$ ) films. 
(a)

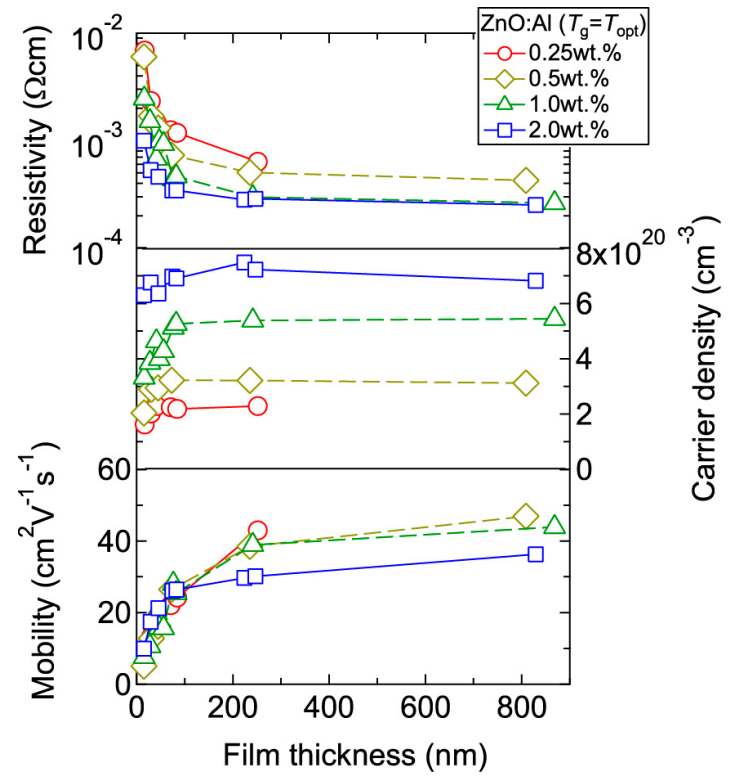

(b)

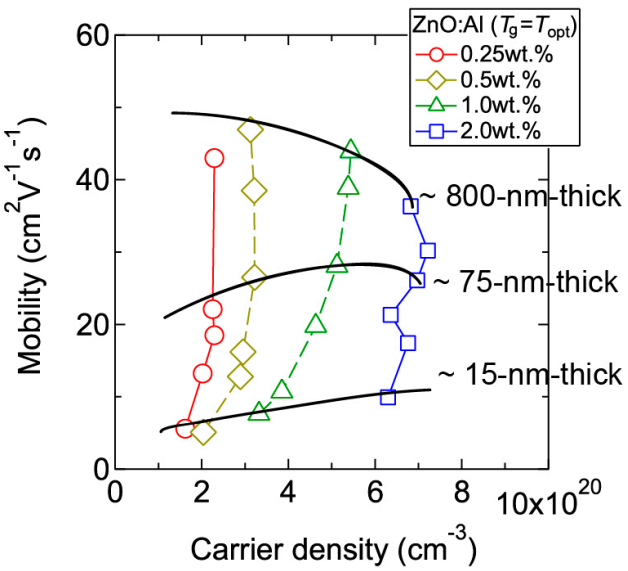

Figure 6. (a) Plots of resistivity, carrier density, and mobility in $\mathrm{ZnO}: \mathrm{Al}(0.25,0.5,1.0$, and 2.0 wt \%) films as a function of film thickness; (b) Relationship between carrier density and mobility for the films.

Figure 7 shows (a) transmittance and reflectance; and (b) absorption coefficient spectra of the 800-nm-thick films grown at $T_{\text {opt }}$. All the films were transparent in visible wavelength region and a decrease in transmittance in near-infrared wavelength region was observed due to free-carrier absorption. In the ultraviolet wavelength region, an onset wavelength, at which absorption began to increase, shifted to shorter wavelengths with increasing $\mathrm{Al}$ content due to Burstein-Moss shift.

(a)

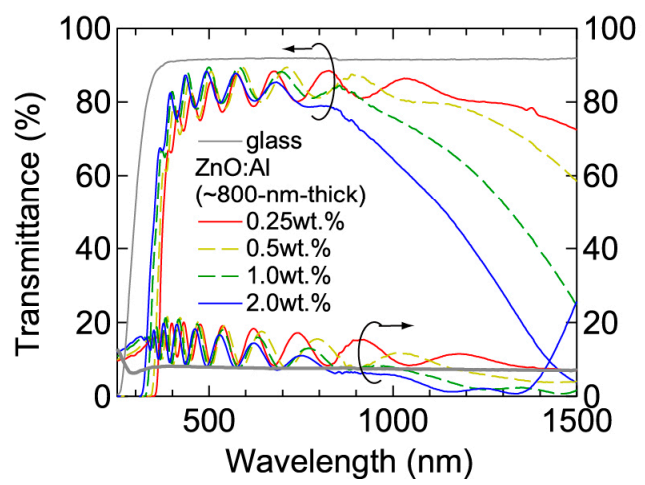

(b)

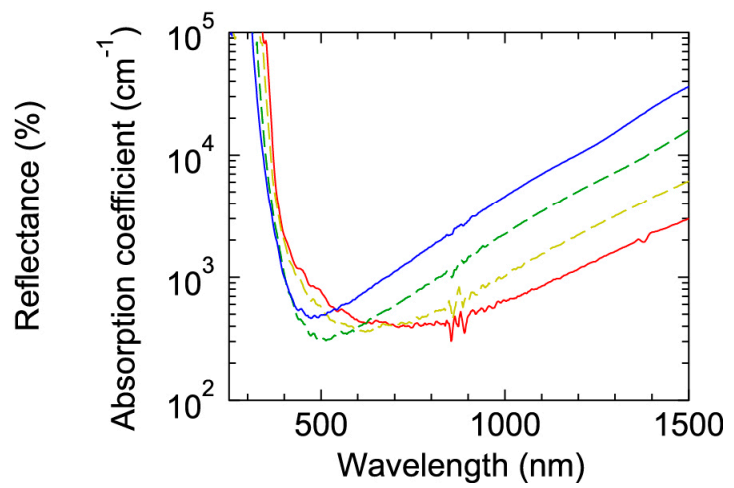

Figure 7. (a) Transmittance and reflectance; and (b) absorption coefficient spectra of the $\sim 800$-nm-thick $\mathrm{ZnO}: \mathrm{Al}(0.25,0.5,1.0$, and $2.0 \mathrm{wt} \%)$ films.

\subsection{Properties of ZnO:Al Films Post-Annealed at Low and High Oxygen Partial Pressures}

We investigated the effects of post-annealing treatments at low $\left(1 \times 10^{-23} \mathrm{~atm}\right)$ and high $\left(1 \times 10^{-4} \mathrm{~atm}\right) P_{\mathrm{O} 2}$ in $\mathrm{ZnO}: \mathrm{Al}(0.25,0.5,1.0,2.0 \mathrm{wt} \%)$ films grown at $T_{\mathrm{opt}}$. Figure 8 shows the changes in $n$ and $\mu$ values for $\mathrm{ZnO}: \mathrm{Al}$ (2.0 wt \%) (Figure 8a) and $\mathrm{ZnO}: \mathrm{Al}$ (0.25 wt \%) (Figure 8b) films at a $P_{\mathrm{O} 2}$ of $1 \times 10^{-23} \mathrm{~atm}$ as a function of specimen temperature $\left(T_{\mathrm{S}}\right)$ during post-annealing using a Hall measurement system. The measurement system is described in Section 3. As shown in Figure 8a, five post-annealing treatments were performed: (i) $50-300-50^{\circ} \mathrm{C}$; (ii) $50-400-50{ }^{\circ} \mathrm{C}$; (iii) $50-500-50{ }^{\circ} \mathrm{C}$; 
(iv) 50-600-50 ${ }^{\circ} \mathrm{C}$; and (v) 50-650-50 ${ }^{\circ} \mathrm{C}$. Closed (open) symbols represent data measured during heating (cooling) in each post-annealing treatment. No large changes in $n$ and $\mu$ were observed up to $400{ }^{\circ} \mathrm{C}$, whereas a large decrease in $n$ was observed with increasing $T_{\mathrm{s}}$ above $400{ }^{\circ} \mathrm{C}$. The values of $n$ during cooling in each annealing treatment were nearly identical to the $n$ value at the maximum annealing temperature $\left(T_{\mathrm{a}}\right)$. Furthermore, the samples also exhibited similar $n$ values during heating in each subsequent annealing treatment up to temperatures less than the maximum $T_{\mathrm{a}}$ in the previous annealing treatment. These results clearly demonstrate that the equilibration time rapidly increases with decreasing $T_{\mathrm{s}}$. Therefore, the $n$ values measured during the cooling process reflect quasi-equilibrium states and frozen defect densities at the maximum $T_{\mathrm{a}}$ of the annealing treatment. Similar changes in $n$ values as a function of $T_{\mathrm{s}}$ were observed for the $\mathrm{ZnO}: \mathrm{Al}(0.25 \mathrm{wt} \%)$ film, as shown in Figure $8 \mathrm{~b}$. However, the changes in $n$ values were very small compared to those of the $\mathrm{ZnO}: \mathrm{Al}(2 \mathrm{wt} \%)$ film. Figure 9 summarizes the changes in $\rho, n$, and $\mu$ values for the $\mathrm{ZnO}: \mathrm{Al}(0.25,0.5,1.0,2.0 \mathrm{wt} \%)$ films measured at room temperature after the post-annealing treatments at a $P_{\mathrm{O} 2}$ of $1 \times 10^{-23} \mathrm{~atm}$. The data are plotted as a function of the maximum $T_{\mathrm{a}}$ in each annealing treatment. Interestingly, the overall behavior on heating was strongly dependent on the $\mathrm{Al}$ content in the films. For the $\mathrm{ZnO}: \mathrm{Al}(0.25 \mathrm{wt} \%)$ film, $\mu$ increased from 42 to 54 whereas $n$ did not change significantly with increasing $T_{\mathrm{a}}$. In contrast, for the $\mathrm{ZnO}: \mathrm{Al}(2.0 \mathrm{wt} \%)$ film, $n$ decreased rapidly at $T_{\mathrm{a}}$ above $400{ }^{\circ} \mathrm{C}$, whereas $\mu$ did not vary at all, as also shown in Figure 8a,b. Furthermore, $n$ values began to decrease at lower $T_{\mathrm{a}}$ values for $\mathrm{ZnO}: \mathrm{Al}$ films with higher Al contents, resulting in $n$ values after the high- $T_{\mathrm{a}}$ annealing treatments that were independent of the $\mathrm{Al}$ content: $5.0-5.3 \times 10^{20} \mathrm{~cm}^{-3}$ for $\mathrm{ZnO}: \mathrm{Al}(2.0$ and $1.0 \mathrm{wt} \%)$ films $\left(T_{\mathrm{a}}=500{ }^{\circ} \mathrm{C}\right)$, 2.8-2.9 $\times 10^{20} \mathrm{~cm}^{-3}$ for $\mathrm{ZnO}: \mathrm{Al}(2.0,1.0$, and $0.5 \mathrm{wt} \%)$ films $\left(T_{\mathrm{a}}=600^{\circ} \mathrm{C}\right)$, and $2.0-2.4 \times 10^{20} \mathrm{~cm}^{-3}$ for $\mathrm{ZnO}: \mathrm{Al}(2.0,1.0,0.5$, and $0.25 \mathrm{wt} \%)$ films $\left(T_{\mathrm{a}}=650^{\circ} \mathrm{C}\right)$.

(a)

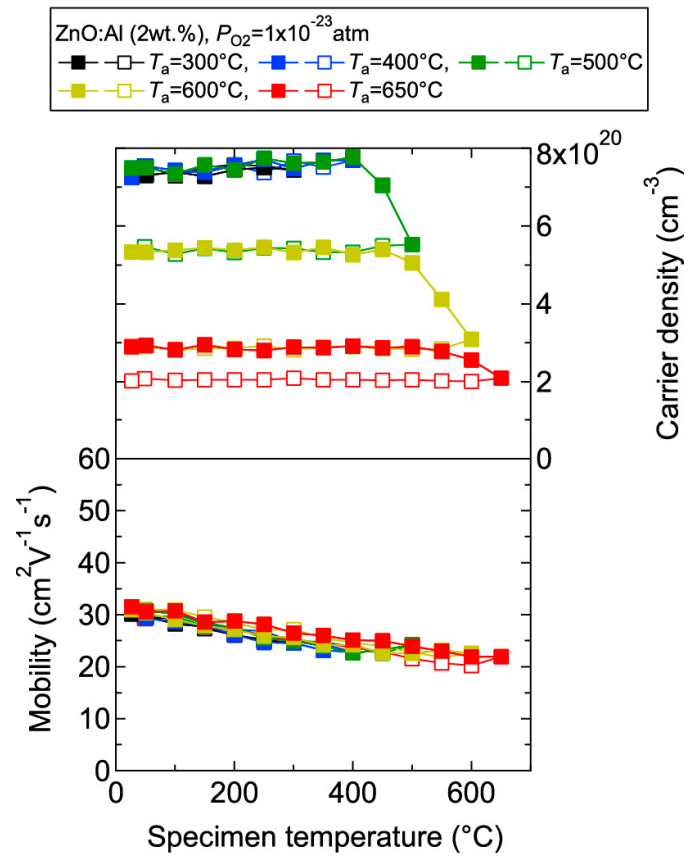

(b)

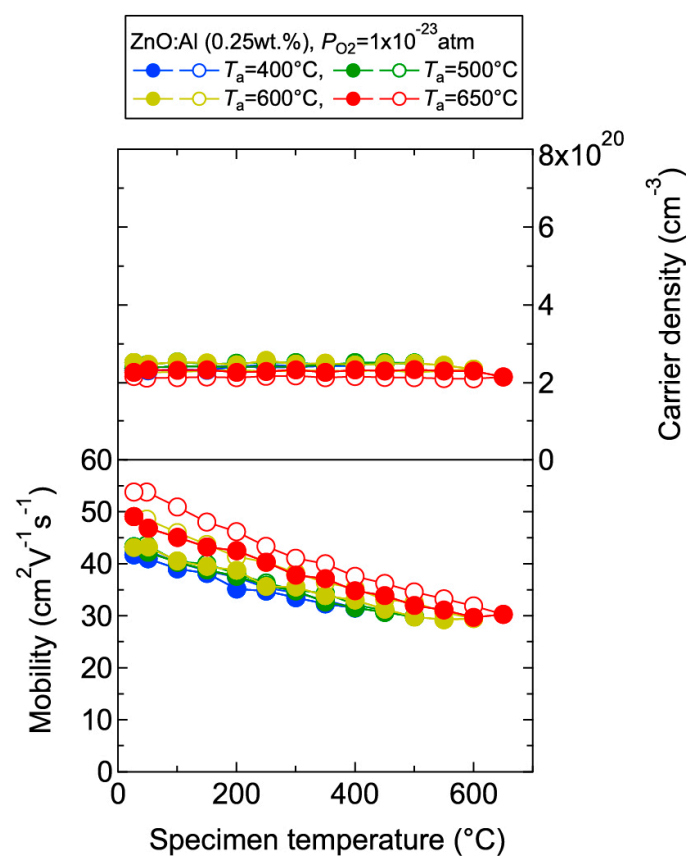

Figure 8. Changes in carrier density and mobility in (a) $\mathrm{ZnO}: \mathrm{Al}(2.0 \mathrm{wt} \%)$ and (b) $\mathrm{ZnO}: \mathrm{Al}(0.25 \mathrm{wt} \%)$ films as a function of specimen temperature during post-annealing treatments at a $P_{\mathrm{O} 2}$ of $1 \times 10^{-23} \mathrm{~atm}$.

The observed changes in $n$ and $\mu$ were dependent on both $T_{\mathrm{a}}$ and $P_{\mathrm{O} 2}$. Figure 10 shows room temperature values of $\rho, n$, and $\mu$ for $\mathrm{ZnO}: \mathrm{Al}(0.25$ and $2.0 \mathrm{wt} \%)$ films plotted as a function of $T_{\mathrm{a}}$ at $P_{\mathrm{O} 2}$ values of $1 \times 10^{-23}$ and $1 \times 10^{-4} \mathrm{~atm}$ (Figure 10a) and the $\mathrm{ZnO}: \mathrm{Al}(0.5 \mathrm{wt} \%)$ films post-annealed at $600{ }^{\circ} \mathrm{C}$ at various $P_{\mathrm{O} 2}$ values (Figure $10 \mathrm{~b}$ ). Figure $10 \mathrm{a}$ indicates that the $\mu$ values for the $\mathrm{ZnO}: \mathrm{Al}$ $(0.25 \mathrm{wt} \%)$ film increased only after post-annealing at low $P_{\mathrm{O} 2}$. In addition, the $n$ values for the $\mathrm{ZnO}: \mathrm{Al}$ 
(0.25 and $2.0 \mathrm{wt} \%$ ) films decreased significantly after annealing at a higher $P_{\mathrm{O} 2}$. Figure $10 \mathrm{~b}$ shows the results for two films that were post-annealed at $600^{\circ} \mathrm{C}$ at different $P_{\mathrm{O} 2}$ values. One film was annealed at a $P_{\mathrm{O} 2}$ of $1 \times 10^{-23} \mathrm{~atm}$ (dotted lines), while the other film was annealed at a $P_{\mathrm{O} 2}$ of $1 \times 10^{-4} \mathrm{~atm}$, followed by an annealing treatment at a $P_{\mathrm{O} 2}$ of $1 \times 10^{-23}$ atm and a subsequent annealing treatment at a $P_{\mathrm{O} 2}$ of $1 \times 10^{-4} \mathrm{~atm}$ (solid lines). Both films exhibited similar transport properties after the annealing treatments at the same $P_{\mathrm{O} 2}\left(1 \times 10^{-23}\right.$ or $\left.1 \times 10^{-4} \mathrm{~atm}\right)$, thereby reflecting their thermodynamic quasi-equilibrium states.

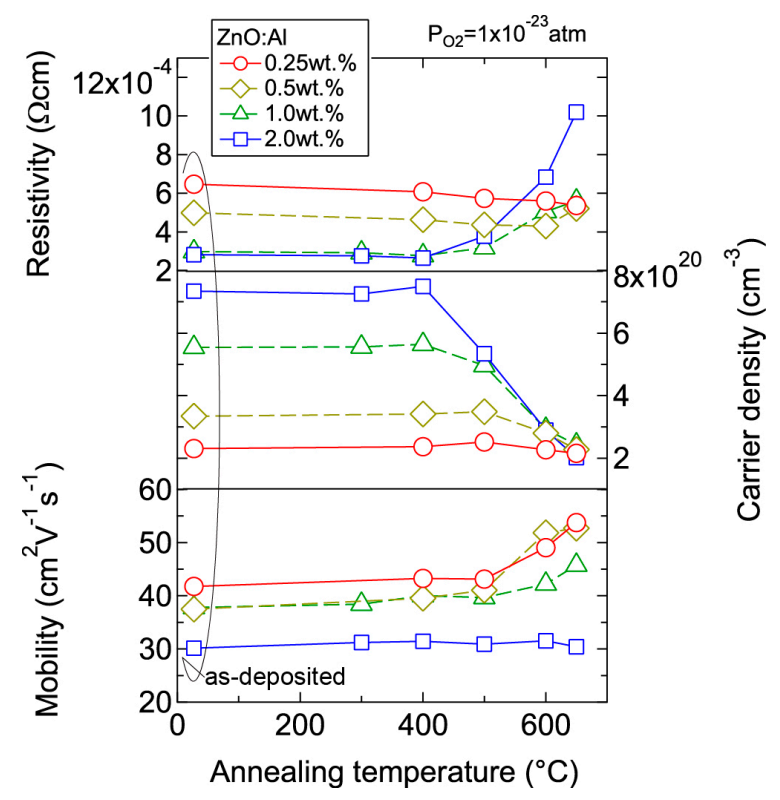

Figure 9. Room-temperature resistivity, carrier density, and mobility in $\mathrm{ZnO}: \mathrm{Al}(0.25,0.5,1.0$, and $2.0 \mathrm{wt} \%)$ films as a function of annealing temperature. Post-annealing was performed at a $P_{\mathrm{O} 2}$ of $1 \times 10^{-23} \mathrm{~atm}$.

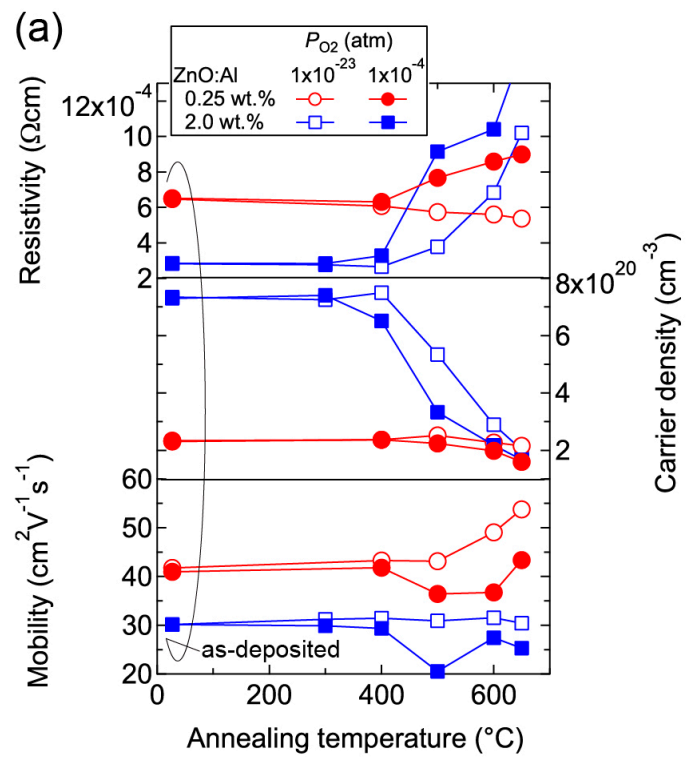

(b)

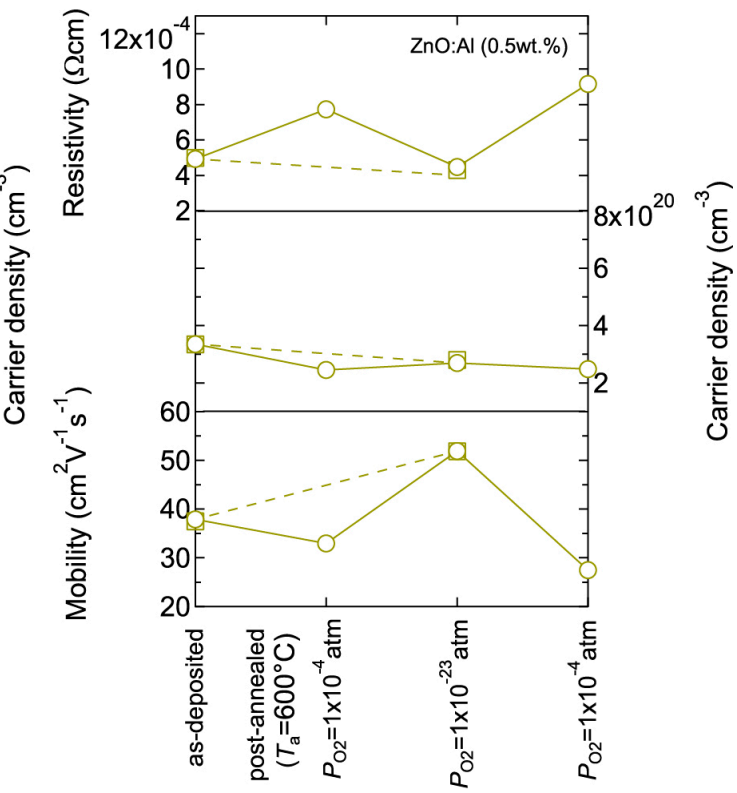

Figure 10. Room-temperature resistivity, carrier density, and mobility in (a) $\mathrm{ZnO}: \mathrm{Al}(0.25$ and $2.0 \mathrm{wt} \%)$ films plotted as a function of annealing temperature at $P_{\mathrm{O} 2}$ values of $1 \times 10^{-23}$ and $1 \times 10^{-4}$ atm and (b) two $\mathrm{ZnO}: \mathrm{Al}(0.5 \mathrm{wt} \%)$ films post-annealed at $600{ }^{\circ} \mathrm{C}$ under various $P_{\mathrm{O} 2}$ values. 
To elucidate the origin of the changes in $n$ and $\mu$, we characterized the structural properties of the films using TEM and XRD, and the chemical properties using X-ray photoelectron spectroscopy (XPS) and thermal desorption spectroscopy (TDS). Figure 11 displays plan-view TEM images of the as-deposited and post-annealed $\mathrm{ZnO}: \mathrm{Al}(0.25$ and $2.0 \mathrm{wt} \%)$ films at $650{ }^{\circ} \mathrm{C}$. Most grain boundaries observed in the films were [001] tilt-type boundaries with a [001] rotation angle. This is because both films exhibited $c$-axis preferred orientations, as indicated by the FWHM $\omega_{002}$ of ca. $2^{\circ}-3^{\circ}$ (Figure 3). Figure 11a,b clearly shows that both of the as-deposited films contained strained regions that propagated toward the grain interior from the GBs. The strained regions are assumed to have been produced by unavoidable orientation mismatches between adjacent columns during crystal growth. After the post-annealing treatment, many of the boundaries appeared flat and located parallel to the $c$-axis at least within a thickness of the TEM foil for both films (Figure 11c,d). This feature may be attributed to grain growth that reduces the grain boundary area to achieving energetically favorable boundaries. Indeed, the FWHM 100 slightly decreased with $T_{\mathrm{a}}$. Figure 12 shows the $a$ - and $c$-axis lengths and cell volume (Figure 12a) along with FWHM $\omega_{002}, \mathrm{FWHM}_{002}$, and FWHM $\mathrm{FWO}_{100}$ (Figure 12b) for the post-annealed films at $P_{\mathrm{O} 2}$ values of $1 \times 10^{-20}$ and $1 \times 10^{-4} \mathrm{~atm}$ as a function of $T_{\mathrm{a}}$. These values were strongly dependent on the $\mathrm{Al}$ content as a result of the strong influence of $T_{\mathrm{g}}$ and thickness on the structural properties, as discussed in Section 2.1. Figure $12 \mathrm{~b}$ shows that the $\mathrm{FWHM}_{002}$ and $\mathrm{FWHM}_{100}$ decreased with $T_{\mathrm{a}}$ above $500{ }^{\circ} \mathrm{C}$, with the same changes observed at both low and high $P_{\mathrm{O} 2}$. Furthermore, no significant differences in the other measured values were detected between the films post-annealed at low and high $P_{\mathrm{O} 2}$. In contrast, the $\mu$ and $n$ values shown in Figure 10 strongly depended on $P_{\mathrm{O} 2}$. Therefore, the decrease in the strained region around the GBs and a slight increase in the in-plane crystallite size indicated in Figures 11 and 12 were not responsible for the increase in $\mu$. Additionally, the different $n$ values produced by post-annealing at different $P_{\mathrm{O} 2}$ values are not due to changes in the structural properties observed by TEM and XRD analysis.

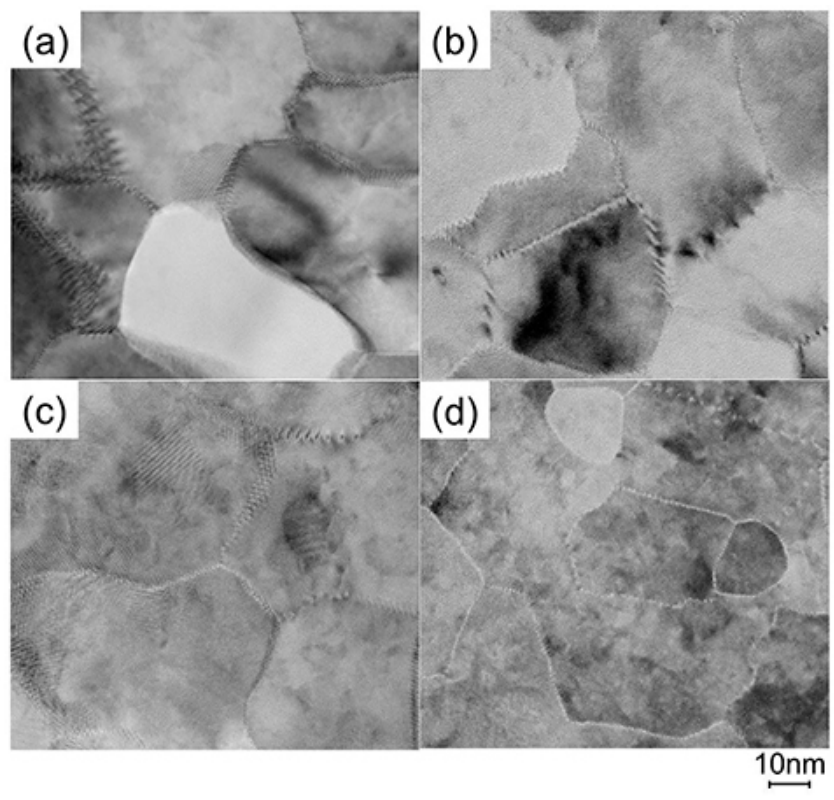

Figure 11. Plan-view TEM images of the as-deposited films of (a) ZnO:Al (0.25 wt \%) and (b) ZnO:Al (2.0 wt \%); and post-annealed films of (c) $\mathrm{ZnO}: \mathrm{Al}(0.25 \mathrm{wt} \%)$ and (d) $\mathrm{ZnO}: \mathrm{Al}(2.0 \mathrm{wt} \%)$ films at $650{ }^{\circ} \mathrm{C}$ at a $P_{\mathrm{O} 2}$ of $1 \times 10^{-23} \mathrm{~atm}$. 
(a)

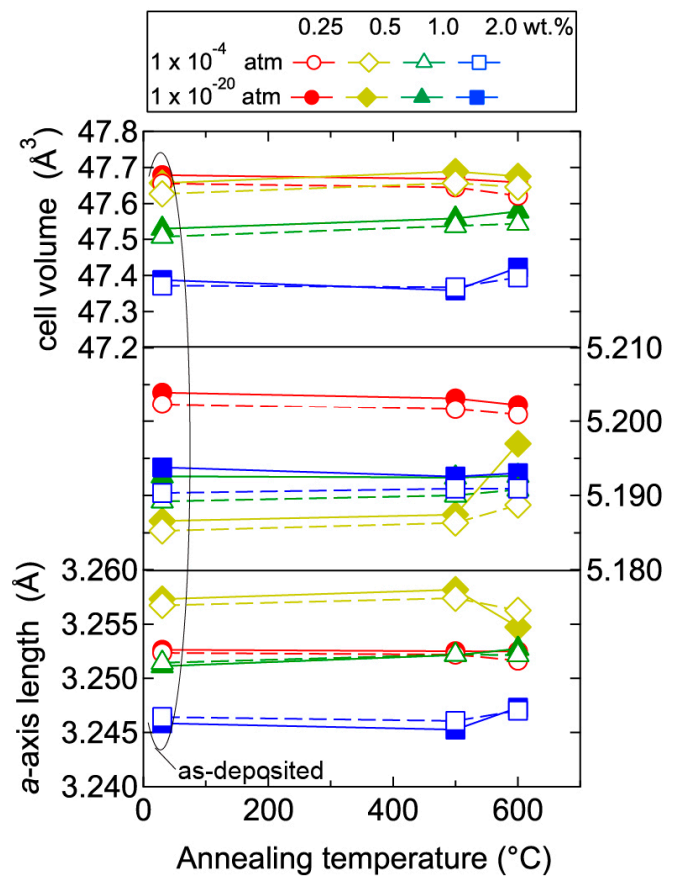

(b)

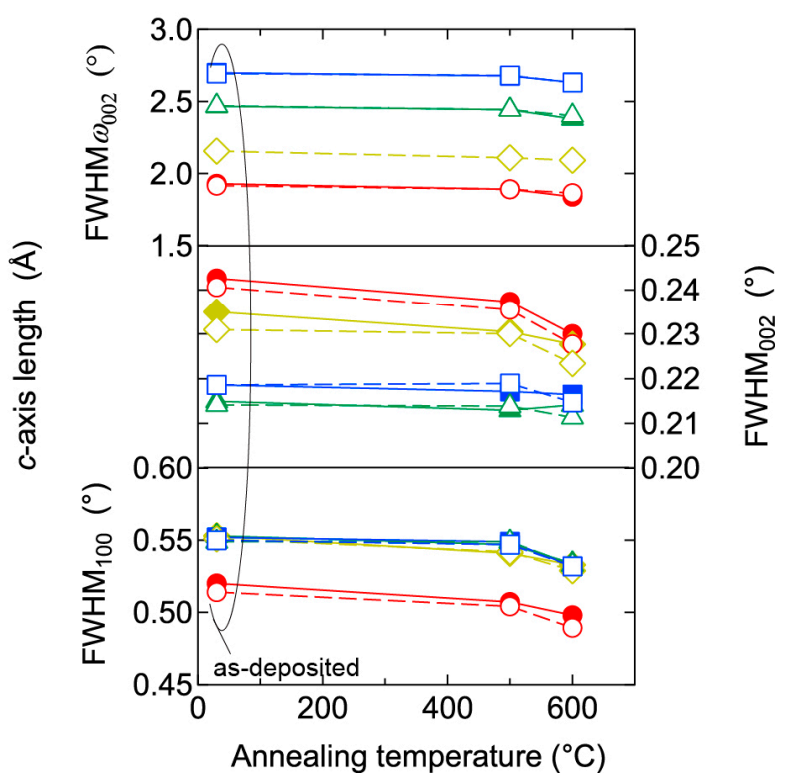

Figure 12. Plots of (a) $a$ - and $c$-axis lengths and cell volumes as a function of annealing temperature, and (b) FWHM of rocking curves for 002 diffraction peaks (FWHM $\omega_{002}$ ) and FWHM of 002 and 100 diffraction peaks $\left(\mathrm{FWHM}_{002}, \mathrm{FWHM}_{100}\right)$ as a function of annealing temperature for films post-annealed at a $P_{\mathrm{O} 2}$ of $1 \times 10^{-20}$ (solid lines) and of $1 \times 10^{-4}$ (dotted lines) atm.

Conversely, high-temperature annealing at low $P_{\mathrm{O} 2}$ is likely to change the chemical properties of the films. Figure 13 shows XPS spectra for the surface regions (Figure 13a) and bulk regions (Figure 13b) of the as-deposited and post-annealed $\mathrm{ZnO}: \mathrm{Al}$ films. Figure 13a indicates that the $\mathrm{Al}$ contents in the surface regions were significantly higher than in the bulk films for both post-annealed $\mathrm{ZnO}: \mathrm{Al}(0.25$ and $2.0 \mathrm{wt} \%)$ films. The concentrations of $\mathrm{Al}, \mathrm{Zn}$, and $\mathrm{O}\left(C_{\mathrm{Al}}(\right.$ at $\%), C_{\mathrm{Zn}}$ (at \%), and $C_{\mathrm{O}}($ at $\%)$ ) estimated from the XPS spectra are summarized in Table 1. The results suggest that minor decomposition of the $\mathrm{ZnO}$ layer occurs in the surface region during high-temperature annealing at low $P_{\mathrm{O} 2}$. This is also supported by the TDS spectra for the $\mathrm{ZnO}$ :Al films. Figure 14 shows the TDS spectra of desorption species from the $\mathrm{ZnO}: \mathrm{Al}(0.25 \mathrm{wt} \%)$ and $\mathrm{ZnO}: \mathrm{Al}(2.0 \mathrm{wt} \%)$ films grown at $T_{\mathrm{opt}}$. We monitored the mass (m/z) of (a) 64; (b) 32; and (c) the ratio between the two. Here, an $\mathrm{m} / \mathrm{z}$ value of 64 includes only $\mathrm{Zn}^{+}$, whereas an $\mathrm{m} / \mathrm{z}$ of 32 includes both $\mathrm{Zn}^{2+}$ and $\mathrm{O}_{2}{ }^{+}$. The behavior of the $\mathrm{m} / \mathrm{z}=32$ signals were similar to those of the $\mathrm{m} / \mathrm{z}=64$ signals with a constant ratio, especially for $T_{\mathrm{s}}$ below $530{ }^{\circ} \mathrm{C}$, thereby indicating that most of the $\mathrm{m} / \mathrm{z}=32$ signals below $530{ }^{\circ} \mathrm{C}$ reflect the desorption of $\mathrm{Zn}$ rather than $\mathrm{O}_{2}$. In contrast, at temperatures above $530^{\circ} \mathrm{C}$, the $\mathrm{m} / \mathrm{z}=32$ signals sharply increased with $T_{\mathrm{s}}$ and exceeded the level of the $\mathrm{m} / \mathrm{z}=64$ signals, thereby indicating that $\mathrm{O}_{2}$ was also desorbed. Hence, decomposition of the films began at $T_{\mathrm{s}}$ values above $500{ }^{\circ} \mathrm{C}$ in a high vacuum (i.e., $<1 \times 10^{-7} \mathrm{~Pa}$ ). 
(a)

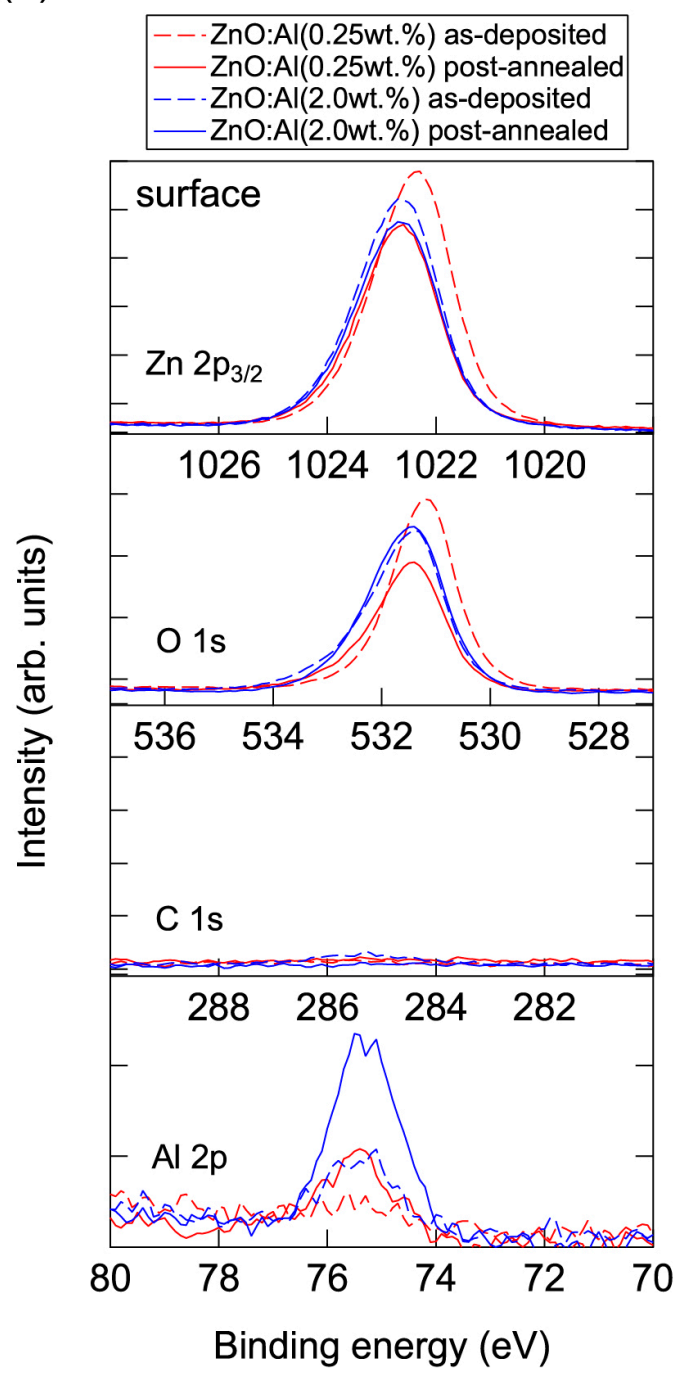

(b)

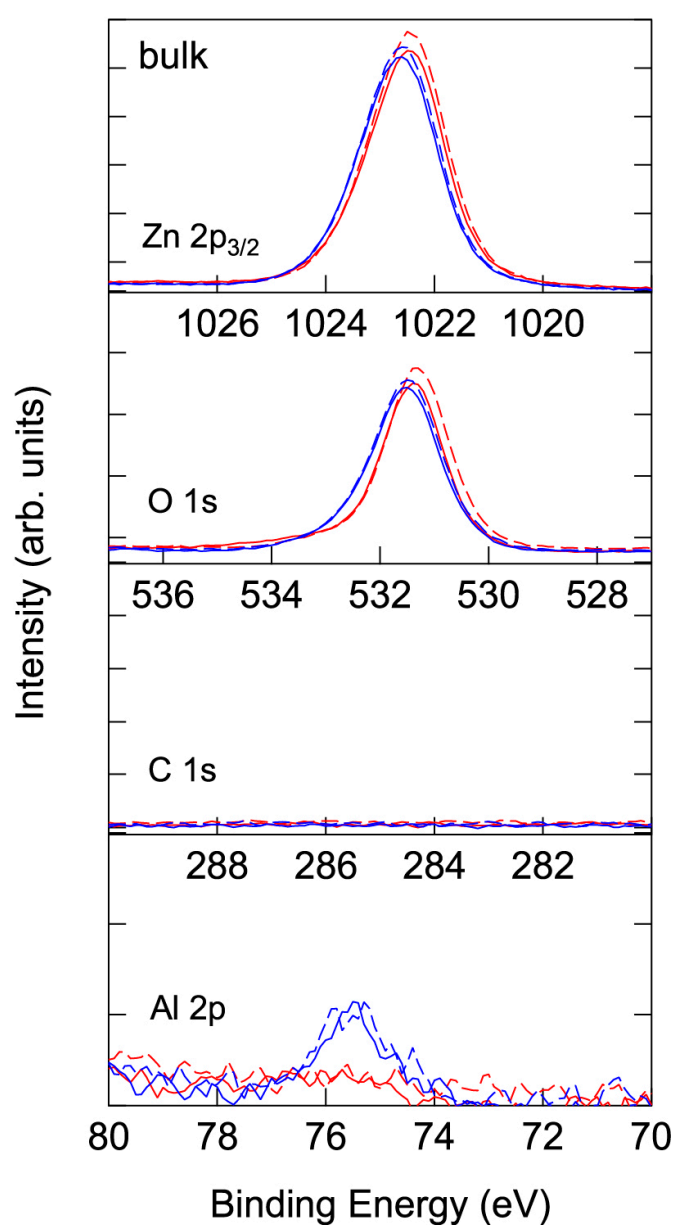

Figure 13. XPS spectra for (a) the surface regions and (b) the bulk regions of the as-deposited and post-annealed $\mathrm{ZnO}: \mathrm{Al}(0.25$ and $2.0 \mathrm{wt} \%)$ films at a $P_{\mathrm{O} 2}$ of $1 \times 10^{-23} \mathrm{~atm}$.

Table 1. The concentrations of $\mathrm{Al}, \mathrm{Zn}$, and $\mathrm{O}\left(C_{\mathrm{Al}}(\right.$ at $\%), C_{\mathrm{Zn}}($ at $\%)$, and $C_{\mathrm{O}}($ at $\%)$ ) estimated from the XPS spectra for the surface and bulk regions of the as-deposited and post-annealed $\mathrm{ZnO}: \mathrm{Al}(0.25$ and $2.0 \mathrm{wt} \%$ ) films at a $P_{\mathrm{O} 2}$ of $1 \times 10^{-23} \mathrm{~atm}$.

\begin{tabular}{cccccc}
\hline \multirow{2}{*}{ Surface } & \multicolumn{2}{c}{ ZnO:Al (0.25 wt \%) } & & \multicolumn{2}{c}{ ZnO:Al (2.0 wt \%) } \\
\cline { 2 - 3 } \cline { 5 - 6 } \cline { 5 - 6 } & As-Deposited & Post-Annealed & & As-Deposited & Post-Annealed \\
\hline$C_{\mathrm{Al}}$ & 0.69 & 3.15 & & 2.04 & 5.94 \\
$C_{\mathrm{Zn}}$ & 48.18 & 48.44 & & 46.10 & 41.52 \\
$C_{\mathrm{O}}$ & 51.13 & 48.41 & & 51.86 & 52.54 \\
\hline \multirow{2}{*}{ Bulk } & \multicolumn{2}{c}{ ZnO:Al (0.25 wt \%) } & & \multicolumn{2}{c}{ ZnO:Al (2.0 wt \%) } \\
\cline { 2 - 3 } & As-Deposited & Post-Annealed & & As-Deposited & Post-Annealed \\
\hline$C_{\mathrm{Al}}$ & 0.46 & 0.65 & & 2.14 & 2.60 \\
$C_{\mathrm{Zn}}$ & 48.52 & 47.85 & & 46.03 & 45.82 \\
$C_{\mathrm{O}}$ & 51.02 & 51.50 & & 51.83 & 51.58 \\
\hline
\end{tabular}


(a)

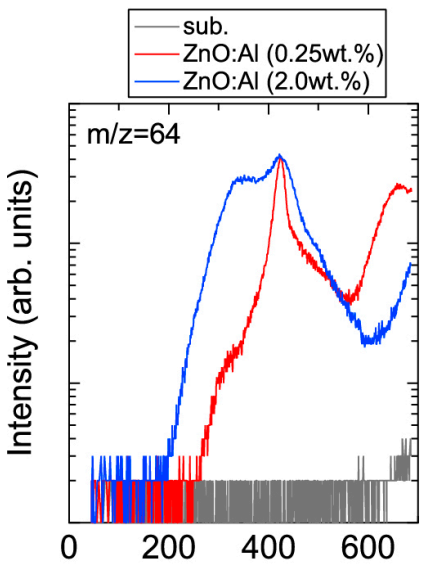

Specimen temperature $\left({ }^{\circ} \mathrm{C}\right)$ (b)

(c)

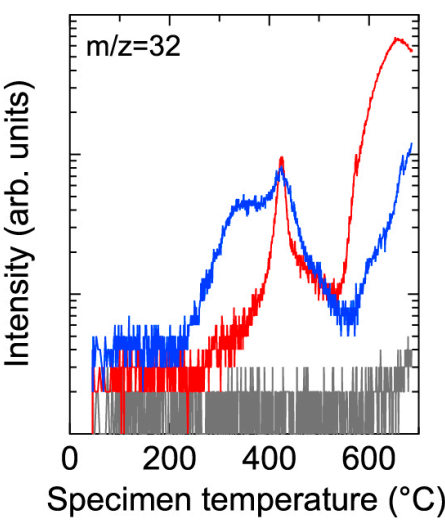

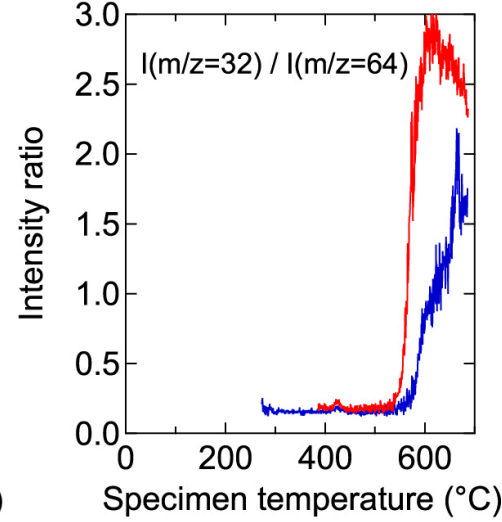

Figure 14. TDS spectra of desorption species with masses (m/z) of (a) 64 and (b) 32 from ZnO:Al $(0.25 \mathrm{wt} \%)$ and $\mathrm{ZnO}: \mathrm{Al}(2.0 \mathrm{wt} \%)$ films grown at optimized temperatures; (c) The intensity ratio of $\mathrm{m} / \mathrm{z}=32$ to $\mathrm{m} / \mathrm{z}=64$.

Prior to the onset of decomposition, defects within grains are likely to change during the post-annealing treatment at high temperatures and at low $P_{\mathrm{O} 2}$. As observed in Figure $14 \mathrm{a}, \mathrm{Zn}$ became desorbed from the surface of the films at temperatures above $\sim 200{ }^{\circ} \mathrm{C}$. Furthermore, a larger amount of $\mathrm{Zn}$ was desorbed from the $\mathrm{ZnO}: \mathrm{Al}(2.0 \mathrm{wt} \%)$ film compared to the $\mathrm{ZnO}: \mathrm{Al}(0.25 \mathrm{wt} \%)$ film. Although the desorption behavior was complex, the signals exhibited peaks at $\sim 350{ }^{\circ} \mathrm{C}$ and $\sim 430{ }^{\circ} \mathrm{C}$ with a shoulder at $\sim 470{ }^{\circ} \mathrm{C}$ in both films. These behaviors are considered to reflect changes in Zn-related defects in the ZnO:Al films. During post-annealing, Zn interstitials diffused from the bulk layers, especially along GBs, and became desorbed from the film surface. A potential source of the $\mathrm{Zn}$ interstitial is excess $\mathrm{Zn}$ inside the films. Another candidate is $\mathrm{Zn}$ interstitials that were generated by the removal of $\mathrm{Zn}$ from the $\mathrm{ZnO}$ lattice along with the generation of $\mathrm{Zn}$ vacancy during the post-annealing treatment, with acceptor-type $\mathrm{Zn}$ vacancy remaining inside the grains. First-principle density functional theory suggests that acceptor-type $\mathrm{v}_{Z n}$ " defects are formed and that carrier compensation occurs in $\mathrm{ZnO}: \mathrm{Al}$ with increasing $P_{\mathrm{O} 2}$ [4-7]. The density of $\mathrm{v}_{\mathrm{Zn}}$ " increases with $\mathrm{Al}$ content in $\mathrm{ZnO}: \mathrm{Al}$ because the formation energy of $\mathrm{vZn}^{\prime \prime}$ decreases with increases in the Fermi energy of $\mathrm{ZnO}$. In addition, $\mathrm{Zn}_{\mathrm{i}} \bullet \bullet$ can diffuse even through the bulk lattice due to a low migration barrier [7]. Based on the combination of these theoretical suggestions, a decrease in $n$ at temperatures above $400{ }^{\circ} \mathrm{C}$-especially for heavily Al-doped $\mathrm{ZnO}$ films at high $P_{\mathrm{O} 2}$ (Figures 9 and 10), desorption of $\mathrm{Zn}$ at these temperatures $\left(\sim 430^{\circ} \mathrm{C}\right)$ under a high vacuum (i.e., $<1 \times 10^{-7} \mathrm{~Pa}$ ) (Figure 14a), and no presence of $\mathrm{Zn}$ vapor during the post-annealing processes under the constant $P_{\mathrm{O} 2}-\mathrm{Zn}$ interstitials and $\mathrm{Zn}$ vacancies are thought to be created in the $\mathrm{ZnO}$ lattice during post-annealing at temperatures above $400{ }^{\circ} \mathrm{C}$. Therefore, $\mathrm{Zn}$ desorption from the films and carrier compensation by acceptor-type $\mathrm{v}_{\mathrm{Zn}}$ " occurred simultaneously. In contrast, desorption of $\mathrm{Zn}$ below $400{ }^{\circ} \mathrm{C}$ had no influence on the $n$ values, as observed in Figure 8, Figure 9, and Figure 14. The results suggest that excess $\mathrm{Zn}$ that does not contribute to carrier generation is present within the as-deposited films. Although the formation energy of a $\mathrm{Zn}_{\mathrm{i}} \bullet \bullet$ is high, and thus high densities of $\mathrm{Zn}_{\mathrm{i}} \bullet \bullet$ are not expected in $\mathrm{ZnO}$ at equilibrium conditions [4,6,7], a large amount of $\mathrm{Zn}$ may be introduced into the films grown using a non-equilibrium growth method, especially when grown under Zn-rich conditions at low temperatures. Indeed, several papers have also reported the detection of $\mathrm{Zn}$ desorption from sputtered $\mathrm{ZnO}$ films in TDS spectra for films grown under low $\mathrm{O}_{2} / \mathrm{Ar}$ flow ratios [19-22]. It should be noted that $\mathrm{Zn}$ desorption decreases with increasing $\mathrm{O}_{2}$ desorption at high $\mathrm{O}_{2} / \mathrm{Ar}$ flow ratios [22]. In addition, we observed a monotonic decrease in $n$ with increases in the $\mathrm{O}_{2} /\left(\mathrm{Ar}+\mathrm{O}_{2}\right)$ flow ratio: $1.7 \times 10^{20}$, 
$3.1 \times 10^{20}, 5.1 \times 10^{20}$, and $5.4 \times 10^{20} \mathrm{~cm}^{-3}$ for $\mathrm{ZnO}$ :Al films grown at a ratio of $1 \%$, compares with $1.4 \times 10^{20}, 2.3 \times 10^{20}, 4.3 \times 10^{20}$, and $3.8 \times 10^{20} \mathrm{~cm}^{-3}$ for $\mathrm{ZnO}$ :Al films grown at a ratio of $2 \%$ with $\mathrm{Al}_{2} \mathrm{O}_{3}$ contents of $0.25,0.5,1.0$, and $2.0 \mathrm{wt} \%$, respectively. These results suggest that thin-film growth during sputtering without the introduction of $\mathrm{O}_{2}$ produces $\mathrm{Zn}$-rich conditions. Such conditions will prevent the generation of large amounts of $\mathrm{v}_{\mathrm{Zn}}$ " during growth and heavy carrier compensation by the $\mathrm{v}_{Z n} "$.

The large increase in $\mu$ after low- $P_{\mathrm{O} 2}$ annealing for $\mathrm{ZnO}: \mathrm{Al}$ films with low $\mathrm{Al}$ contents can be explained by a reduction in scattering centers at GBs. As described in Section 2.1, $\mu$ for the ZnO:Al films is influenced by GB scattering in addition to scattering from ionized impurities. Figure 10b illustrates that $\mu$ increased after low- $P_{\mathrm{O} 2}$ annealing, whereas $\mu$ decreased after high- $P_{\mathrm{O} 2}$ annealing. As shown in Figure 12, no notable change in the structural properties was observed between the films post-annealed at low and high $P_{\mathrm{O} 2}$. In contrast, we detected a change in the chemical states of the film surfaces by XPS and TDS measurements in films post-annealed at low $P_{\mathrm{O} 2}$. These results suggest that point defects at GBs that act as scattering centers are reduced by low- $P_{\mathrm{O} 2}$ annealing. Conversely, we did not observe any increase in $\mu$ in a post-annealed $\mathrm{ZnO}: \mathrm{Al}(2.0 \mathrm{wt} \%)$ film with a similar $n$ value, likely due to an increase in the compensation ratio by the generation of large amount of $\mathrm{V}_{\mathrm{Zn}}{ }^{\prime \prime}$, as discussed above.

Based on these results, carrier compensation occurs by the generation of $\mathrm{v}_{Z n}$ "acceptor-type defects when sputtered $\mathrm{ZnO}: \mathrm{Al}$ films are post-annealed at high temperatures. The compensation behavior differs with $\mathrm{Al}$ content. For high- $\mathrm{Al} \mathrm{ZnO}$ :Al films (i.e., $2.0 \mathrm{wt} \%$ ), $n$ starts to decrease at $\sim 400{ }^{\circ} \mathrm{C}$ even at a low $P_{\mathrm{O} 2}$ of $1 \times 10^{-23} \mathrm{~atm}$, whereas in low-Al films (i.e., $0.25 \mathrm{wt} \%$ ), $n$ starts to decrease at $\sim 600{ }^{\circ} \mathrm{C}$. Furthermore, the amount of desorbed $\mathrm{Zn}$ and the amount of acceptor-type defects estimated from the changes in $n$ values increase with $\mathrm{Al}$ content. These results are in good agreement with theoretical predictions [6]. Practical applications require higher $n$ and $\mu$ values. Low- $P_{\mathrm{O} 2}$ annealing is effective in increasing $\mu$ values, likely due to reduction in the amount of point defects at GBs that act as scattering centers. However, at present, $n$ values are small compared to the $\mathrm{Al}$ content and a portion of the free carriers is likely to be trapped by crystal imperfections, as described in Section 2.1. In this case, controlling the presence of tilt-type GBs in Zn-rich conditions will be important [23]. Additionally, $\mathrm{Zn}$ vacancies and other related defects have been detected in as-deposited $\mathrm{ZnO}$ films by positron annihilation [24,25]. Self-compensation by the production of $\mathrm{V}_{Z n}$ " has also been experimentally demonstrated for as-deposited Ga-doped $\mathrm{ZnO}$ films [10]. Therefore, passivation of the existing $\mathrm{ZZn}^{\prime \prime}$ defects by a post-annealing treatment can be useful. For example, post-annealing in a $\mathrm{Zn}$ atmosphere is a candidate method for reducing $\mathrm{v}_{\mathrm{Zn}}$ " concentrations. Experimental studies have also reported that post-annealing treatments in a $\mathrm{Zn}$ atmosphere improve both $n$ and $\mu$ values [26,27]. Also, hydrogen has been proposed to passivate acceptor-type cation vacancies [28]. Other experiments have also found that annealing treatments in forming gas $\left(5 \%-10 \% \mathrm{H}_{2} /\right.$ balance $\mathrm{Ar}$ or $\left.\mathrm{N}_{2}\right)[10,27,29]$ and hydrogen diffusion from $\mathrm{SiN}_{\mathrm{X}}: \mathrm{H}$ or a-Si:H layers [30,31] can improve both $n$ and $\mu$ values.

\section{Materials and Methods}

$\mathrm{ZnO}: \mathrm{Al}$ thin films were grown on heated alkali-free glass (Corning \#1737) and $\mathrm{SiO}_{2}$-coated Si using a radio frequency magnetron sputtering system. Sintered $\mathrm{ZnO}$ ceramic targets containing $0.25,0.5,1.0$, and $2.0 \mathrm{wt} \% \mathrm{Al}_{2} \mathrm{O}_{3}$ powder were used as source materials and the radio frequency power density during sputtering was $4.4 \mathrm{~W} \cdot \mathrm{cm}^{-2}$. The distance between the target and the substrates (three glass and one $\mathrm{SiO}_{2}$-coated $\mathrm{Si}$ of $50 \times 50 \mathrm{~mm}$ in size) was $100 \mathrm{~mm}$ and the base pressure in the deposition chamber prior to deposition was $\sim 2 \times 10^{-5} \mathrm{~Pa}$. High-purity Ar gas was introduced at a gas flow rate of $\sim 50 \mathrm{sccm}$ and the deposition pressure was $0.2 \mathrm{~Pa}$. $\mathrm{No} \mathrm{O}_{2}$ gas was introduced to the deposition chamber. The film thicknesses were varied from 15 to $800 \mathrm{~nm}$. The growth temperatures for $\mathrm{ZnO}: \mathrm{Al}$ $(0.25,0.5,1.0$, and $2.0 \mathrm{wt} \%)$ films were $200-370,250-390,300-400$, and $300-450{ }^{\circ} \mathrm{C}$, respectively. After deposition, some films were post-annealed in $\mathrm{N}_{2}$ at a constant $P_{\mathrm{O} 2}$ using an oxygen pump [32,33]. These films were grown at 370, 350, 300, and $250{ }^{\circ} \mathrm{C}$ for $\sim 240$-nm-thick $\mathrm{ZnO}: \mathrm{Al}(0.25,0.5,1.0$, and $2.0 \mathrm{wt} \%$ ) films, respectively. 
Figure 15a shows a schematic image of our experimental setup, which contains an oxygen pump and a Hall measurement system. The oxygen pump is composed of a solid electrolyte tube made of yttria-stabilized zirconia (YSZ). Platinum electrodes are attached to both its outer and inner surfaces and the YSZ tube is heated up to $700{ }^{\circ} \mathrm{C}$. When $\mathrm{N}_{2}$ gas flows into the tube, the residual $\mathrm{O}_{2}$ molecules in the $\mathrm{N}_{2}$ gas are ionized at the surface of the inner electrode. The oxygen ions are then moved to the outer electrode by an electric field between the two electrodes, which results in the oxygen molecules being swept away outside the tube. This allows the $P_{\mathrm{O} 2}$ of the $\mathrm{N}_{2}$ gas to be reduced during the flow through the tube. The $P_{\mathrm{O} 2}$ can be controlled within the range of $\sim 1 \times 10^{-4}$ to $\sim 1 \times 10^{-28}$ atm by adjusting the electric field between the two electrodes. The oxygen pump is connected to the Hall measurement system and $P_{\mathrm{O} 2}$ is monitored using oxygen sensors located at the inlet and outlet of the oxygen pump. Figure 15b shows an example of $P_{\mathrm{O} 2}$ variations in the experimental setup in which $P_{\mathrm{O} 2}$ gradually decreased down to less than $1 \times 10^{-23}$ atm and then $P_{\mathrm{O} 2}$ was immediately increased to $1 \times 10^{-4}$ atm by changing the electric field. The $\rho, n$, and $\mu$ values of the films were obtained in a van der Pauw configuration. The Hall measurement system incorporates a heating system and the electrical properties can be measured at high temperatures of up to $650{ }^{\circ} \mathrm{C}$ in $\mathrm{N}_{2}$. The $T_{\mathrm{s}}$ values were monitored using a thermocouple located just behind the substrate. Most of the specimens on glass with a size of $\sim 10 \times 10 \mathrm{~mm}$ were post-annealed during the $(\rho, n, \mu)$ measurements, however some larger specimens on glass of $50 \times 50 \mathrm{~mm}$ in size were post-annealed in a quartz furnace to characterize their structural properties using XRD. Figure 15c displays a plot of temperature before and after each $(\rho, n, \mu)$ measurement as a function of time. Electrical properties were measured every $50{ }^{\circ} \mathrm{C}$ while heating from 50 to $650{ }^{\circ} \mathrm{C}$ and were subsequently cooled from 650 to $50^{\circ} \mathrm{C}$ with a ramping and cooling rate of $\sim 10 \mathrm{~K} \cdot \mathrm{min}^{-1}$. The average time needed to achieve a constant temperature for the $(\rho, n, \mu)$ measurements was approximately $30 \mathrm{~min}$, therefore, the entire measurement sequence was performed over $12 \mathrm{~h}$. It should be noted that these annealing times are not sufficient to produce equilibrium states at the annealing temperatures used, and that the equilibration time will decrease with increases in $T_{\mathrm{S}}$.

(a)

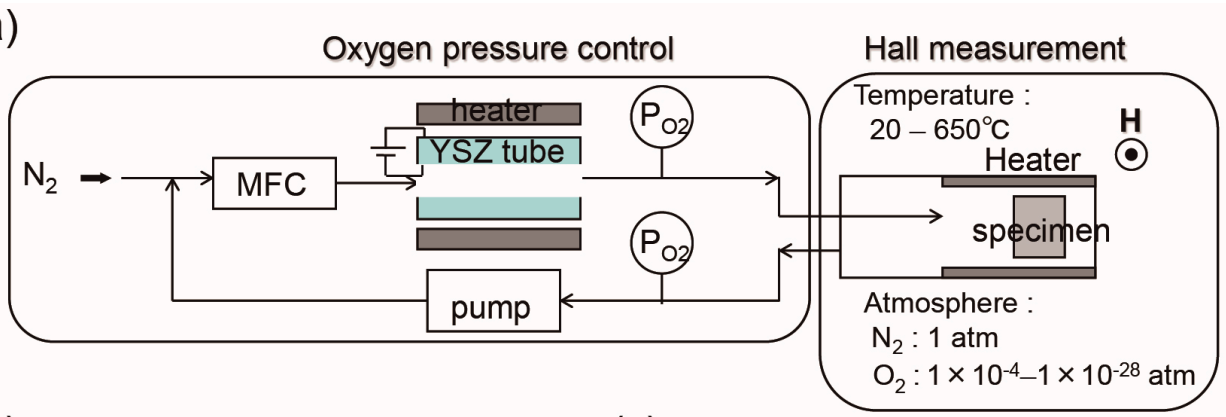

(b)

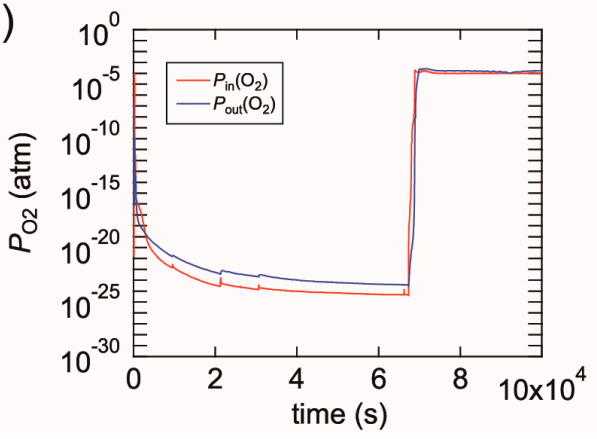

(c)

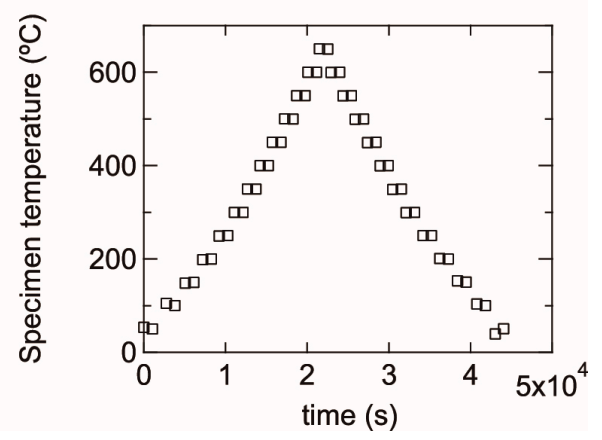

Figure 15. (a) A schematic image of our experimental setup composed of an oxygen pump and a Hall measurement system; (b) example diagram of $P_{\mathrm{O} 2}$ variations as a function of time. The $P_{\mathrm{O} 2}$ was controlled by changing the electric field between the inner and outer electrodes of a solid electrolyte tube made of yttria-stabilized zirconia (YSZ); (c) temperatures during $(\rho, n, \mu)$ measurements as a function of time. In this measurement, the electrical properties were measured every $50{ }^{\circ} \mathrm{C}$ during heating from 50 to $650{ }^{\circ} \mathrm{C}$ and subsequent cooling from 650 to $50{ }^{\circ} \mathrm{C}$. 
Figure 16a shows a thermodynamic equilibrium diagram between $\mathrm{ZnO}$ and $\mathrm{Zn}+1 / 2 \mathrm{O}_{2}$ for pure $\mathrm{ZnO}$. $\mathrm{ZnO}$ decomposes at high temperatures and low $P_{\mathrm{O} 2}$. In our experiments, $\mathrm{ZnO}$ : $\mathrm{Al}$ film decomposition was observed in certain conditions. Figure $16 \mathrm{~b}$ contains an image of a $\mathrm{ZnO}: \mathrm{Al}$ $(0.25 \mathrm{wt} \%)$ film post-annealed at $600{ }^{\circ} \mathrm{C}$ at a $P_{\mathrm{O} 2}$ of $1 \times 10^{-28} \mathrm{~atm}$ using the Hall measurement system. Decomposition occurred in the center area of the film along with a reduction in thickness. The $(\rho, n, \mu)$ measurements described in this study were performed with post-annealing up to $650{ }^{\circ} \mathrm{C}$ at a $P_{\mathrm{O} 2}$ of $1 \times 10^{-4}$ and of $1 \times 10^{-23} \mathrm{~atm}$. At these conditions, we observed no change in color as a result of the reduction in thickness.

The chemical properties and composition of the films were analyzed by XPS using a monochromatic Al-K $\alpha$ X-ray source. To avoid carbon contamination at the surface, $\mathrm{Ar}^{+}$ion etching was lightly performed until the carbon signal disappeared prior to the XPS measurements on the film surface regions. Conversely, XPS measurements on the bulk film regions were performed after extended $\mathrm{Ar}^{+}$ion etching. The crystal structures were analyzed by XRD and TEM. $\theta-2 \theta$ scan (out-of-plane) and $2 \theta_{x}-\varphi$ scan (in-plane) XRD measurements using $\mathrm{Cu}-\mathrm{K} \alpha$ radiation were performed. TDS was used to evaluate gas desorption during post-annealing. The base pressure of the TDS system was less than $2 \times 10^{-8} \mathrm{~Pa}$. For TDS measurements, the films were characterized on $\mathrm{SiO}_{2}$-coated $\mathrm{Si}$ with a size of $10 \times 10 \mathrm{~mm}$ with a constant specimen heating rate of $\sim 16{ }^{\circ} \mathrm{C} \cdot \mathrm{min}^{-1}$ using an infrared lamp. The annealing temperature was monitored using a thermocouple in contact with the specimen. The desorbed gases from the specimens were identified using a quadrupole mass spectrometer.

(a)

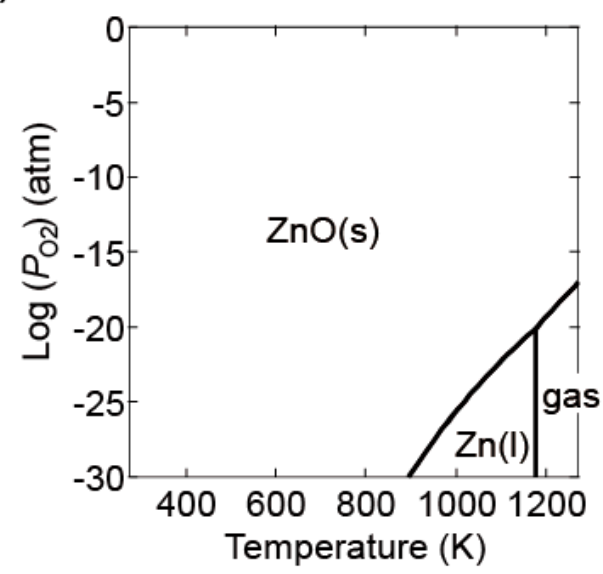

(b)

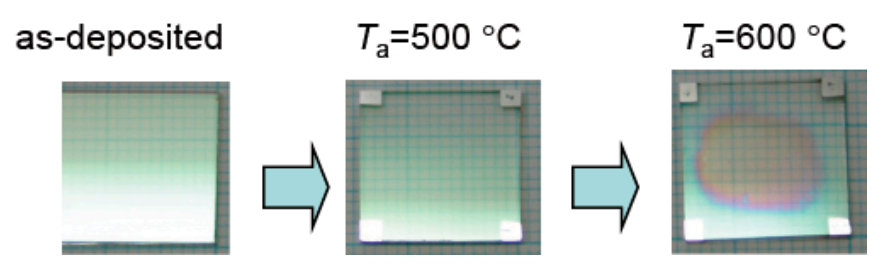

Figure 16. (a) Diagram indicating the conditions of thermodynamic equilibrium between $\mathrm{ZnO}$ and $\mathrm{Zn}+1 / 2 \mathrm{O}_{2}$ for pure $\mathrm{ZnO}$; (b) images of a $\mathrm{ZnO}: \mathrm{Al}(0.25 \mathrm{wt} \%)$ film before and after post-annealing at 500 and $600{ }^{\circ} \mathrm{C}$ at a $P_{\mathrm{O} 2}$ of $1 \times 10^{-28}$ atm using the Hall measurement system. 


\section{Conclusions}

Carrier compensation effects induced by post-annealing treatments under low and high $P_{\mathrm{O} 2}$ were investigated in $\mathrm{ZnO}: \mathrm{Al}$ films. The $\mathrm{ZnO}: \mathrm{Al}$ films were deposited by sputtering $\mathrm{ZnO}: \mathrm{Al}$ ceramic targets (with $0.25,0.5,1.0$, and $2.0 \mathrm{wt} \% \mathrm{Al}_{2} \mathrm{O}_{3}$ ) under optimized growth conditions. The as-deposited films were post-annealed in $\mathrm{N}_{2}$ at a $P_{\mathrm{O} 2}$ of $1 \times 10^{-23}$ or $1 \times 10^{-4} \mathrm{~atm}$, controlled by an oxygen pump. The variations of the $n$ and $\mu$ values during the post-annealing treatment were evaluated using a Hall measurement system. Both values were found to strongly depend on the $\mathrm{Al}$ content and $P_{\mathrm{O} 2}$. For the $\mathrm{ZnO}: \mathrm{Al}(0.25 \mathrm{wt} \%)$ film, the $\mu$ value increased from 42 to $54 \mathrm{~cm}^{2} \cdot \mathrm{V}^{-1} \cdot \mathrm{s}^{-1}$ whereas $n$ exhibited similar values $\left(2.3-2.2 \times 10^{20} \mathrm{~cm}^{-3}\right)$ after post-annealing at $650^{\circ} \mathrm{C}$ at a $P_{\mathrm{O} 2}$ of $1 \times 10^{-23} \mathrm{~atm}$. In contrast, the $\mathrm{ZnO}: \mathrm{Al}(2.0 \mathrm{wt} \%)$ film exhibited $n$ values that significantly decreased from $7.3 \times 10^{20}$ to $2.0 \times 10^{20} \mathrm{~cm}^{-3}$ whereas $\mu$ exhibited similar values $\left(\sim 30 \mathrm{~cm}^{2} \cdot \mathrm{V}^{-1} \cdot \mathrm{s}^{-1}\right)$ after the same post-annealing treatment. Furthermore, the decrease in $n$ values began at a lower $T_{\mathrm{a}}$ for $\mathrm{ZnO}$ :Al films with higher $\mathrm{Al}$ contents and this temperature further decreased with increasing $P_{\mathrm{O} 2}$. Based on an analysis of the Hall, XRD, TEM, TDS, and XPS data, we concluded the following. (i) Post-annealing at temperatures above $\sim 200{ }^{\circ} \mathrm{C}$ promotes desorption of $\mathrm{Zn}$ that was introduced into the films under non-equilibrium growth and $\mathrm{Zn}$-rich conditions. These growth conditions likely suppress the generation of $\mathrm{Zn}$ vacancies in the lattice during growth. In addition, the $\mathrm{Zn}$ desorbed at temperatures below $400{ }^{\circ} \mathrm{C}$ does not contribute to carrier generation in the as-deposited films; (ii) Post-annealing at temperatures above $400{ }^{\circ} \mathrm{C}$ generates acceptor-type $\mathrm{Zn}$ vacancies in the lattice along with desorption of $\mathrm{Zn}$ from the films, which results in carrier compensation. In addition, the defect density increases with $\mathrm{Al}$ content and $P_{\mathrm{O} 2}$; (iii) High-temperature (i.e., $>500{ }^{\circ} \mathrm{C}$ ) annealing at low $P_{\mathrm{O} 2}$ (i.e., $1 \times 10^{-23} \mathrm{~atm}$ ) is effective in increasing $\mu$, likely due to the reduction in point defects at GBs that act as carrier scattering centers.

Acknowledgments: This work was partly supported by New Energy and Industrial Technology Development Organization (NEDO) under Ministry of Economy, Trade and Industry (METI), Japan.

Author Contributions: Takashi Koida conceived and designed the experiments, and wrote the paper; Tetsuya Kaneko performed the XPS measurements; Hajime Shibata gave some important suggestions.

Conflicts of Interest: The authors declare no conflict of interest.

\section{References}

1. Niki, S.; Contreras, M.; Repins, I.; Powara, M.; Kushiya, K.; Ishizuka, S.; Matsubara, K. CIGS absorbers and processes. Prog. Photovot. Res. Appl. 2010, 18, 453-466. [CrossRef]

2. Minami, T. New $n$-type transparent conducting oxides. MRS Bull. 2000, 25, 38-44. [CrossRef]

3. Coutts, T.J.; Young, D.L.; Li, X. Characterization of transparent conducting oxides. MRS Bull. 2000, 25, 58-65. [CrossRef]

4. Kohan, A.F.; Ceder, G.; Morgan, D.; Van de Walle, C.G. First-principles study of native point defects in ZnO. Phys. Rev. B 2001, 61, 15019-15027. [CrossRef]

5. Zhang, S.B.; Wei, S.-H.; Zunger, A. Intrinsic n-type versus p-type doping asymmetry and the defect physics of ZnO. Phys. Rve. B 2001, 63, 075205. [CrossRef]

6. Lany, S.; Zunger, A. Dopability, intrinsic conductivity, and nonstoichiometry of transparent conducting oxides. Phys. Rev. Lett. 2007, 98, 045501. [CrossRef] [PubMed]

7. Janotti, A.; Van de Walle, C.G. Native pint defects in ZnO. Phys. Rev. B 2007, 76, 165202. [CrossRef]

8. Klein, A.; Korber, C.; Wachau, A.; Sauberlich, F.; Gassenbauer, Y.; Harvery, S.P.; Proffit, D.E.; Mason, T.O. Transparent conducting oxides for photovoltaics: Manipulation of firmi level, work function and energy band alignment. Materials 2010, 3, 4892-4914. [CrossRef]

9. Zakutayev, A.; Perry, N.H.; Mason, T.O.; Ginley, D.S.; Lany, S. Non-equilibrium origin of high electrical conductivity in gallium zinc oxide thin films. Appl. Phys. Lett. 2013, 103, 232106. [CrossRef] 
10. Look, D.C.; Leedy, K.D.; Vines, L.; Svensson, B.G.; Zubiaga, A.; Tuomisto, F.; Doutt, D.R.; Brillson, L.J. Self-compensation in semiconductors: The Zn vacancy in Ga-doped ZnO. Phys. Rev. B 2011, 84, 115202. [CrossRef]

11. Hupkes, J.; Rech, B.; Calnan, S.; Kluth, O.; Zastrow, U.; Siekmann, H.; Wuttig, M. Material study on reactively sputtered zinc oxide for thin film silicon solar cells. Thin Solid Films 2006, 502, 286-291. [CrossRef]

12. Berginski, M.; Hupkes, J.; Schulte, M.; Schope, G.; Stiebig, H.; Wuttig, M. The effect of front ZnO:Al surface texture and optical transparency on efficient light trapping in silicon thin-film solar cells. J. Appl. Phys. 2007, 101, 074903. [CrossRef]

13. Shirouzu, K.; Ohkusa, T.; Hotta, M.; Enomoto, N.; Hojo, J. Distribution and solubility limit of $\mathrm{Al}$ in $\mathrm{Al}_{2} \mathrm{O}_{3}$-doped $\mathrm{ZnO}$ sintered body. J. Ceram. Soc. Jpn. 2007, 115, 254-258. [CrossRef]

14. Yoshioka, S.; Oba, F.; Huang, R.; Tanaka, I.; Mizoguchi, T.; Yamamoto, T. Atomic structures of supersaturated $\mathrm{ZnO}-\mathrm{Al}_{2} \mathrm{O}_{3}$ solid solutions. J. Appl. Phys. 2008, 103, 014309. [CrossRef]

15. Vinnichenko, M.; Gago, R.; Cornelius, S.; Shevchenko, N.; Rogozin, A.; Kolitsch, A.; Munnik, F.; Moller, W. Establishing the mechanism of thermally induced degradation of $\mathrm{ZnO}: \mathrm{Al}$ electrical properties using synchrotron radiation. Appl. Phys. Lett. 2010, 96, 141907. [CrossRef]

16. Seto, J.Y.W. The electrical properties of polycrystalline silicon films. J. Appl. Phys. 1975, 46, 5247. [CrossRef]

17. Ellmer, K.; Mientus, R. Carrier transport in polycrystalline ITO and ZnO:Al II: The influence of grain barriers and boundaries. Thin Solid Films 2008, 516, 5829-5835. [CrossRef]

18. Cornelius, S.; Vinnichenko, M.; Shevchenko, N.; Rogozin, A.; Kolitsch, A.; Moller, W. Achieving high free electron mobility in $\mathrm{ZnO}: \mathrm{Al}$ thin films grown by reactive pulsed magnetron sputtering. Appl. Phys. Lett. 2009, 94, 042103. [CrossRef]

19. Hiramatsu, T.; Furuta, M.; Furuta, H.; Matsuda, T.; Hirao, T. Influenc of thermal annealing on microstructures of zinc oxide films deposited by RF magnetron sputtering. Jpn. J. Appl. Phys. 2007, 46, 3319-3323. [CrossRef]

20. Yamada, T.; Miyake, A.; Makino, H.; Yamamoto, N.; Yamamoto, T. Effect of thermal annealing on electrical properties of transparent conductive Ga-doped $\mathrm{ZnO}$ films prepared by ion-plating using direct-current arc discharge. Thin Solid Films 2009, 517, 3134-3137. [CrossRef]

21. Makino, H.; Sato, Y.; Yamamoto, N.; Yamamoto, T. Changes in electrical and optical properties of polycrystalline Ga-doped $\mathrm{ZnO}$ thin films due to thermal desorption of zinc. Thin Solid Films 2011, 520, 1407-1410. [CrossRef]

22. Matsuda, T.; Furuta, M.; Hiramatsu, T.; Furuta, H.; Li, C.; Hirao, T. Thermal stability of ZnO thin film prepared by RF-magnetron sputtering evaluated by thermal desorption spectroscopy. Appl. Suf. Sci. 2010, 256, 6350-6353. [CrossRef]

23. Nomoto, J.; Inaba, K.; Osada, M.; Kobayashi, S.; Makino, H.; Yamamoto, T. Highly (0001)-oriented Al-doped ZnO polycrystalline films on amorphous glass substrates. J. Appl. Phys. 2016, 120, 125302. [CrossRef]

24. Uedono, A.; Koida, T.; Tsukazaki, A.; Kawasaki, M.; Chen, Z.Q.; Chichibu, S.F.; Koinuma, H. Defects in ZnO thin films grown on $\mathrm{ScAlMgO}_{4}$ substrates probed by a monoenergetic positron beam. J. Appl. Phys. 2003, 93, 2481-2485. [CrossRef]

25. Tuomisto, F.; Ranki, V.; Saarinen, K.; Look, D.C. Evidence of the Zn vacancy acting as the dominant acceptor in n-type ZnO. Phys. Rev. Lett. 2003, 91, 205502. [CrossRef] [PubMed]

26. Zhan, Z.; Zhang, J.; Zheng, Q.; Pan, D.; Huang, J.; Huang, F.; Lin, Z. Strategy for preparing Al-doped ZnO thin film with high mobility and high stability. Cryst. Growth Des. 2011, 11, 21-25. [CrossRef]

27. Look, D.C.; Leedy, K.D. Making highly conductive ZnO: Creating donors and destroying acceptors. Proc. SPIE 2012, 8263, 826302.

28. Varley, J.B.; Peelaers, H.; Janotti, A.; Van de Walle, C.G. Hydrogenated cation vacancies in semiconducting oxides. J. Phys. Condens. Matter 2011, 23, 334212. [CrossRef] [PubMed]

29. Scottt, R.C.; Leedy, K.D.; Bayraktaroglu, B.; Look, D.C.; Smith, D.J.; Ding, D.; Lu, X.; Zhang, Y.J. Influence of substrate temperature and post-deposition annealing on material properties of Ga-doped ZnO prepared by pulsed laser deposition. Electron. Mater. 2011, 40, 419-428. [CrossRef]

30. Ruske, F.; Roczen, M.; Lee, K.; Wimmer, M.; Gall, S.; Hupkes, J.; Hrunski, D.; Rech, B. Improved electrical transport in Al-doped zinc oxide by thermal treatment. J. Appl. Phys. 2010, 107, 013708. [CrossRef]

31. Wimmer, M.; Ruske, F.; Scherf, S.; Rech, B. Improving the electrical and optical properties of DC-sputtered ZnO:Al by thermal post deposition treatments. Thin Solid Films 2012, 520, 4203-4207. [CrossRef] 
32. Nagai, I.; Shirakawa, N.; Ikeda, S.; Iwasaki, R.; Nishimura, H.; Kosaka, M. Highest conductivity oxide $\mathrm{SrMoO}_{3}$ grown by a floating-zone method under ultralow oxygen partial pressure. Appl. Phys. Lett. 2005, 87, 024105. [CrossRef]

33. Ohya, Y.; Yamamoto, T.; Ban, T. Equilibrium dependence of the conductivity of pure and tin-doped indium oxide on oxygen partial pressure and formation of an intrinsic defect cluster. J. Am. Ceram. Soc. 2008, 91, 240-245. [CrossRef]

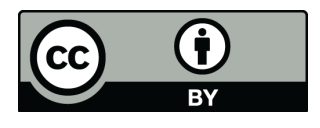

(c) 2017 by the authors; licensee MDPI, Basel, Switzerland. This article is an open access article distributed under the terms and conditions of the Creative Commons Attribution (CC BY) license (http://creativecommons.org/licenses/by/4.0/). 